NBER WORKING PAPER SERIES

\title{
DO PRIVATE SCHOOLS PROVIDE COMPETITION FOR PUBLIC SCHOOLS?
}

Caroline Minter Hoxby

Working Paper No. 4978

\section{NATIONAL BUREAU OF ECONOMIC RESEARCH 1050 Massachusetts Avenue Cambridge, MA 02138 \\ December 1994}

I am grateful to Henry Farber, James Poterba, Michael Piore, Franklin Fisher, David Card, Jonathan Gruber, Steve Pischke, all of the members of the Princeton Industrial Relations Section, and seminar participants at Princeton, M.I.T. and Harvard for many helpful comments. I gratefully acknowledge funding from a Ford Foundation Dissertation Fellowship, a Spencer Foundation Fellowship for Research Related to Education, a National Science Foundation Graduate Fellowship, and the Bradley Foundation. All errors are my own. This paper is part of NBER's research program in Public Economics. Any opinions expressed are those of the author and not those of the National Bureau of Economic Research.

(C) 1994 by Caroline Minter Hoxby. All rights reserved. Short sections of text, not to exceed two paragraphs, may be quoted without explicit permission provided that full credit, including $($ ) notice, is given to the source. 


\title{
DO PRIVATE SCHOOLS PROVIDE \\ COMPETITION FOR PUBLIC SCHOOLS?
}

\begin{abstract}
Arguments in favor of school choice depend on the idea that competition between schools improves the quality of education. However, we have almost no empirical evidence on whether competition actually affects school quality. In this study, I examine the effects of inter-school competition on public schools by using exogenous variation in the availability and costs of private school alternatives to public schools. Because low public school quality raises the demand for private schools as substitutes for public schools, we cannot simply compare public school students' outcomes in areas with and without substantial private school enrollment. Such simple comparisons confound the effect of greater private school competitiveness with the increased demand for private schools where the public schools are poor in quality. I derive instruments for private school competition from the fact that it is less expensive and difficult to set up religious schools, which accounts for 9 out of 10 private school students in the U.S., in areas densely populated by members of the affiliated religion. I find that greater private school competitiveness significantly raises the quality of public schools, as measured by the educational attainment, wages, and high school graduation rates of public school students. In addition, I find some evidence that public schools react to greater competitiveness of private schools by paying higher teacher salaries.

Caroline Minter Hoxby Department of Economics Harvard University Cambridge, MA 02138 and NBER
\end{abstract}




\section{I.}

\section{Introduction}

School choice is one of the most hotly debated suggestions for improving the quality of education in the United States. The central argument for school choice is that inter-school competition for students improves school quality. However, we have almost no empirical evidence on whether school quality is actually affected by competition. In this study, I provide evidence on the effect of inter-school competition on the quality of public schools (measured by ultimate educational attainment, wages, and high school graduation rates) that relies on exogenous variation in the costs of private-school alternatives to public schools.

Increased private school competitiveness may affect public schools in several ways. The two main possibilities are (1) that competition compels public schools to improve school quality, and (2) that as private schools become more competitive alternatives to public schools, increased sorting of students among schools takes place. ${ }^{1}$ Such sorting might take place on lines of student ability, student personality, or parents' tastes regarding school curriculum and atmosphere. While increased sorting would not directly affect public school quality, it might have indirect effects through changes in the student and parent populations.

Because low public school quality raises the demand for private schools as substitutes for public schools, we cannot simply compare public school students' outcomes in areas with and without substantial private school enrollment. Such simple comparisons confound the effect of

\footnotetext{
${ }^{1}$ Greater private school competition simply means that parents find private schools a more competitive alternative to public schools. I do not intend to imply that private schools satisfy economic notions of perfect competition.
} 
greater private school competitiveness with the increased demand for private schools where public schools are poor in quality. Formally, private school enrollment is likely to be endogenous to public school quality, and this endogeneity will lead to downward-biased estimates of the competitive effect of greater private school enrollment.

I obtain unbiased estimates of the effect of private school competition using an instrumental variables approach. Specifically, I use the fact that it is less expensive and difficult to set up a religious private school in an area densely populated by members of that religion. Religious private schools account for $87 \%$ of U.S. private school enrollment, with Catholic schools alone accounting for $80 \%$ of private school enrollment. ${ }^{2}$ Since religious composition of an area is largely a matter of historical accident, it is not likely to have an independent effect on public school quality. ${ }^{3}$ Religious composition is thus a good exogenous measure of potential competition for public schools because it is strongly correlated with costs of private schools but is uncorrelated with other sources of demand for private schools (poor underlying public school quality).

\section{II.}

\section{A Simple Model of Public Schools, Private Schools and Parents}

This section describes the important interactions among public schools, private schools,

2 Statistics are for 1980 and refer to regular schooling.

${ }^{3}$ In particular, the Catholic population of any given area depends on several historical events since Catholicism is associated with many ethnic groups that have different settlement histories. Prominent examples are English Catholics (Maryland), French Catholics (Louisiana), German Catholics (many areas), Irish Catholics (many areas), Eastern European Catholics (many areas), and Hispanics (southeastern and southwestern U.S., other areas). 
and parents that determine which students attend which schools and the quality offered by each school. The model begins with a Tiebout-type model of local public goods provision and makes two important extensions.

Suppose that each town is a school district, and that each town has a fixed housing stock. Consider a local educational market: the towns that a household considers as places of residence given its employment situation. ${ }^{4}$ This local educational market has an urban or rural character, town boundaries, income distribution, educational distribution, racial composition, and religious composition. Households have children, whose ability and personality are known. A household's utility is a function of the education produced in its children, its tastes for education generally and private or religious education particularly, the quality of its house, the distances from job to home and from home to school, and the other services provided by its city of residence.

In the absence of private schools, households allocate themselves among school districts by maximizing their utility subject to constraints imposed by income, job location, and the abilities and personalities of their children. With fixed town boundaries, the level at which public schooling will be provided in each town must be equilibriated by means of local property tax

\footnotetext{
4 For estimation purposes, the best available approximation of the an individual's local educational market is the county or, in metropolitan areas, the standard metropolitan statistical area (SMSA) or New England County Metropolitan Area (NECMA) which are aggregated counties. For the remainder of this paper, I refer to this combination of counties and metropolitan areas simply as "counties," though I use SMSAs and NECMAs in metropolitan areas. An ideally defined market avoids two potential problems. If the market definition is too narrow, then parents who care more about education are likely to move across market boundaries to get better schooling for their children, and estimates are biased because parents in markets with better schools systemically care more about education. Clearly, the ideal market is wider than a single school district. On the other hand, if the market definition is too broad, we miss local critical masses of a denomination's members which make that denomination's private schools more competitive. A local educational market defined by a state would be far too wide because Catholics, say, might be very prevalent in one part of the state even if the state's Catholic population density was average. While counties are far from perfect indicators of the local market for schooling, they are generally broad enough to limit the potential endogeneity problem caused by parents who move to live near better schools. Also, they are generally narrow enough to register local critical masses of a denomination's members. No better parition of the available data exists.
} 
rates and capitalization of the value of local public schooling into house prices. These means do not, in general, produce an efficient equilibrium (where each household's demand for public schooling is exactly satisfied and public schooling is provided at minimum average cost). ${ }^{5}$ To the extent that the resulting equilibrium is not efficient, there will be a demand for private schooling.

A private school exists when it can offer schooling that is so much closer to the demands of a sufficient number of households that the households in question are willing to cover its costs (in addition to whatever property taxes they must continue to pay for public schools). Private schools may have the same production function as public schools, in which case they attract households by catering to demands of a certain type. Alternatively, private schools may have different production functions--because, for instance, they have greater latitude in disciplining students-and select students who are particularly susceptible to their style of production.

In a market with both public and private schools, households solve their constrained maximization problem as follows. Each household chooses, for each private school in the market, the town in which it would be best to live. Next, the household chooses the best combination of private school and town of residence, and compares this choice to the best package of a public school and its town. The household demands a house in the town and a place in the school, public or private, that make up the maximizing combination. We now come to the first important extension of the model: a theory of how the degree of private school competition may vary among areas. Though far from being a pure public good, schooling is most often provided in a "public" way because, one, fixed costs are a large share of total costs

\footnotetext{
${ }^{5}$ See Tiebout (1956), Courant (1977), Akin and Youngday (1976), Barlow (1970), Brueckner (1979, 1983), and Bloom et al (1983).
} 
and, two, because people wish to spread the cost educating their children over their lifetimes. Public schools financed by property taxes are one means of managing these circumstances. Private schools will be more competitive alternatives as they find find means of reducing fixed costs and of spreading costs over people's lifetimes. Affiliation with a religious denomination provides both of these means: fixed costs are reduced by sharing between churches and schools; the denomination's members contribute funds to reduce the tuition charges faced by parents' with school-age children. The next section provides empirical evidence for these assertions and the more specific assertion that the competitiveness of private schools in an area may be summarized by the population densities of certain denominations.

The second important extension of the model is a theory of how private school competition may influence public school conduct. What follows are not claims, but merely two possible routes by which private schools may affect public school administrators and teachers. First, suppose that a town's residents cannot readily observe the productivity of school personnel because both teaching and the product of teaching (value-added to students' learning) are difficult to evaluate. Then, we have a classic principal-agent problem in which the principals (the residents) seek means by which they can enforce higher productivity on the part of the agents (the school personnel). The more private schools are a competitive alternative to public schools, the more information about the agents' productivity will be contained in the private schools' enrollment share. Consider an area in which private schools have few means of reducing fixed costs or spreading costs: the private schools' enrollment share will largely reflect the share of local people rich enough to cover the full costs of educating a child privately and/or the share of local people whose extraordinary tastes make private education worth a extraordinarily large 
share of their incomes. In constrast, consider an area in which private schools have greatly reduced fixed costs and effective means of spreading costs: more parents will be on the margin between public and private education, and the private schools' enrollment share will provide information about parents' relative satisfaction in the public and private schools. Thus, greater competitiveness of private schools furnishes residents with more information about school productivity, allowing residents' reactions to possibly enforce greater productivity.

Second, greater private school competitiveness may provide greater financial incentives for school staffs. Through voting on tax rates and capitalization of the value of public schools into house prices, the total property tax income for public schools in a town will vary more with residents' satisfaction when private schools are a more competitive alternative. However, when private schools are a more competitive alternative, the number of students in the public schools will also vary more with residents' satisfaction. Thus, it is clear that private school competitiveness makes the total school budget depend positively on public school productivity, but it is not clear that the per-pupil school budget will depend positively on public school productivity. The per-pupil budget may, perversely, rise when the satisfaction with the public schools falls. If there were no fixed costs of providing public schooling, school personnel would almost certainly prefer higher per-pupil budgets regardless of the total school budget. To the extent that fixed costs are important, the utility of school personnel may fall with the total school budget, regardless of the per-pupil budget. Thus, greater private school competitiveness will improve the financial incentives faced by schools if per-pupil budgets as well as total school budgets depend positively on public school productivity or if school personnel care about total school budgets rather than per-pupil budgets. Greater private school competitiveness will worsen 
the financial incentives faced by schools if the personnel care only about per-pupil budgets and per-pupil budgets depend negatively on public school productivity.

\section{III.}

\section{Implications of the Model}

I have suggested two possible mechanisms by which greater private school competitiveness may stimulate greater public school productivity. If public schools do indeed raise productivity in response to private school competition, note that they will almost certainly do so by raising quality, not by keeping quality constant and reducing tax rates. Reduced tax rates translate into higher disposable income which parents can spend on private school tuition.

While the model proposes means by which private school competitiveness may affect public school conduct, the model clearly implies that greater private school competitiveness will increase the degree of student sorting among schools. Increasing the alternatives available to households can only have a non-negative effect on the degree to which parents' preferences and students' abilities determine the choice of school. Thus, we expect that private school competitiveness will affect public school student populations, if not public school conduct. Empirical evidence on the effects of private school competition must attempt to distinguish between changes in student populations and in conduct. Note that the model provides no indication of what type of sorting will occur or how important a phenomenon sorting will be. Sorting may occur along ability lines (the most or least able children tend to enroll in private schools), along personality lines (the most disruptive children tend to enroll in private schools), 
or along taste lines (parents with the most pronounced tastes for untraditional curricula or for "moral" atmosphere choose private schools).

The model also implies that lower public school quality, all else equal, will cause more parents to demand private schooling, causing private school enrollment to rise. We can partially explain public school quality in an area by examining area characteristics such as public school concentration, the income and educational distributions, and racial composition. Nevertheless, part of public school quality will remain unexplained and unexplained low quality can be confounded with increased private school competitiveness, causing a simultaneity problem for estimates.

Note that homogeneity of the population will affect the degree to which public schooling provision is efficient and the competitiveness of private schools. For instance, a very homogeneous population is likely to obtain public schooling that closely matches its demands. A population that contains a few disparate groups, which are homogeneous in themselves, will be able support private schools efficiently. Thus, we also need to be alert to the possibility of confounding the effects of population homogeneity on public schools with the effects of private school competition.

IV.

\section{Empirical Strategy}

The empirical strategy must allow us to distinguish among the implications described above, first by determining the sign and size of the effect of private school competitiveness on public schools, next by distinguishing between the mechanisms that can generate an effect of the 
sign and size found. To estimate the effects of private school competitiveness, I summarize the model in two equations, the first a reduced form education production function and the second a reduced form equation showing the determinants of private school enrollment. In linear form, the first equation is:

$$
y_{i j}=X_{j}+X_{j} \beta_{1}+X_{i j} \beta_{2}+\omega_{j}+v_{j}+\varepsilon_{i j}
$$

where $\mathrm{i}$ indexes individuals, $\mathrm{j}$ indexes schooling markets, $\mathrm{y}$ is a public schooling outcome, $\mathrm{C}$ is the (potentially endogenous) share of enrollment in private schools, $\mathbf{X}_{\mathrm{j}}$ is a vector of exogenous schooling market descriptors, $\mathbf{X}_{\mathrm{ij}}$ is a vector of exogenous individual descriptors, $\omega_{\mathrm{j}}$ is unexplained public school quality, $v_{\mathrm{j}}$ is a market-specific error term, and $\varepsilon_{\mathrm{ij}}$ is an individualspecific error term. Student outcomes $(y)$ such as educational attainment, wages, or test scores are used to measure public school productivity. The measure of private school competitiveness is $\mathrm{C}$, included to allow private school competition to affect public school conduct or the public school student population.

The reduced form equation showing the determinants of the private school enrollment share, $\mathrm{C}$, is:

$$
C_{j}=\mathbf{R}_{j} \alpha_{1}+\mathbf{X}_{j} \alpha_{2}+\alpha_{3} \omega_{j}+\zeta_{j}
$$

where $\mathbf{R}_{j}$ is a vector of denominational variables describing the population of schooling market $\mathrm{j}, \mathbf{X}_{\mathrm{j}}$ is the vector of exogenous schooling market descriptors, $\omega_{\mathrm{j}}$ is unexplained public school quality, and $\zeta_{\mathrm{j}}$ is a market-specific error term. The denominational variables, $\mathbf{R}_{\mathrm{j}}$, affect the private schools' ability to reduce fixed costs and spread costs. Recall that $\omega_{j}$ is included because the demand for private schooling is a decreasing function of unexplained public school quality.

It is clear from equations 1 and 2 that the private school enrollment share is potentially 
endogenous to public school quality, implying that simple OLS type estimates of $\gamma$ will be biased. I obtain an instrumental variables (IV) estimate of $\gamma$ using the vector of denominational variables, $\mathbf{R}_{\mathbf{j}}$, as identifying instruments. This IV estimate is consistent if denominational population variables affect private school competitiveness but not public schools. The usefulness of denominational variables as instruments is shown by the next section and by econometric tests of the identifying restrictions.

Since we are interested in whether private school competitiveness provides improved or worse financial incentives for public schools, I also estimate the equation 1 by IV with teacher salaries, per-pupil spending, and per-resident spending (a measure of the total school budget) as dependent variables. ${ }^{6}$

\section{V.}

\section{How Private School Costs Depend on Religious Composition}

The empirical strategy outlined above depends on the fact that the greater a denomination's population density in an area, the better able are its schools to compete with the public schools. There are several structural reasons why a denomination's schools compete more strongly with the public schools in areas where that denomination claims a large share of the population--that is, why more parents find themselves on the margin between a public and private school. First, a significant share of a denominational school's revenues typically come from

- Other school characteristics, such as the student-teacher ratio, were also tried in an effort to further describe the effects of private school competitiveness on public school conduct. These results indicated insignificant effects and, for brevity's sake, are not presented. 
church offerings, which are drawn from all denominational members regardless of whether their children currently attend the schools. This system allows cost spreading over parents' lifetimes and has the efficient quality that members who place greater value on the public good (the denominational school) will contribute more. Denominational schools set tuitions as low as is consistent with a balanced budget. In areas where a denomination is prevalent, tuition is lower or more places are offered at a given tuition. Second, denominational schools reduce fixed costs by sharing buildings, equipment, and personnel with churches and synagogues. The contributed services of members of religious orders are particularly important. Third, parents almost certainly prefer schools affiliated with their own denomination or affiliated with a denomination common in the area, so more parents are on the margin between public school and a denominational school in an area where that denomination prevails. Finally, an area densely populated by a denomination's members can support schools at shorter distances from one another so that parents are more likely to find a private school alternative located nearby. Transportation expenses often represent a large proportion of the cost of sending a child to private school, and both public and private school parents cite locational convenience as a major factor in their school choice?

We can examine these four points with specific reference to the Catholic Church, by far the largest single denomination in the U.S. There are three types of Catholic schools: parochial, run by a parish, $96 \%$ being elementary schools; diocesan, under the control of a bishop, $70 \%$ being elementary and $30 \%$ being secondary; and private, usually owned by an order such as the Jesuits, $85 \%$ being either secondary or combined elementary and secondary. In 1980 , there were

\footnotetext{
'Private Schools in the United States: A Statistical Profile, with Comparisons to Public Schools, p. 121.
} 
173 dioceses or archdioceses in the U.S. which oversaw the 18,829 parishes, and there were 8,051 parochial or diocesan schools. Additionally, there were 791 private Catholic schools. $^{8}$ Parochial schools cover, on average, $54 \%$ of their operating costs with parish "subsidies" from church offerings. Their costs would increase by $29 \%$, on average, if they paid the normal salaries at their schools to the teachers who contribute their services. Diocesan schools cover, on average, $26 \%$ of their costs with "subsidies" and would have $35 \%$ higher costs without contributed services. Both Parochial and Diocesan schools set tuition to cover the remaining costs after subsidies, public funds, and other sources of income are exhausted. If a school falls into deficit, the diocese can ask nearby, richer parishes to give some of their offerings to help it balance its budget. Virtually no redistribution takes place between dioceses. ${ }^{9}$ Therefore, local offerings and the services of local religious orders almost completely determine both the tuition and the number of school places that can be offered at any given tuition at Catholic schools, especially Parochial and Diocesan schools.

Table 1 shows that a higher Catholic population density has several important effects on an area: the number of parishes per diocese is higher, the number of Catholics per parish is higher, the numbers of Catholic schools and school places per person are higher, and the percentage of teachers in Catholic schools who contribute their services is higher. There are not only more parishes per diocese, but the dioceses are much smaller in square miles in those regions of the U.S. where the Catholic population density is high. ${ }^{10}$ Also, states and cities with

\footnotetext{
${ }^{8}$ The Official Catholic Directory 1981, p. 1.

${ }^{9}$ Larson, pp. 247, 295.

${ }^{10}$ The Official Catholic Directory, maps.
} 
high population densities of Catholics are more likely to provide school bus transportation for private school students at public expense. ${ }^{11}$ Taken together, these facts imply that a household living in an area with a high Catholic population density is more likely to live in a parish that is (1) geographically small, (2) supports a school, (3) contains a large number of Catholics, and (4) contains more people in religious orders willing to contribute their services to Catholic schools. Such parents face lower tuition, more available school places, a shorter distance to the closest Catholic school, fewer school transportation difficulties, and a neighborhood where other children attend Catholic school. ${ }^{12}$

Note, however, that between areas with similar Catholic population densities, there remains variation in whether Catholic schools actually exist. Historical reasons for this variation include individual Bishops and other church leaders, the prominence of certain religious orders and missionary movements during the period of settlement, and the intolerance of other religious groups.

In 1980, private schools accounted for $12 \%$ of total U.S. elementary and secondary school enrollment. Catholic schools accounted for the largest share by far: about $80 \%$ of regular elementary and secondary private school enrollment. However, other denominations, particularly Lutherans, are also important providers of schooling:

\footnotetext{
${ }^{11}$ Author's calculations using school transportation laws described in State and Federal Laws Relating to Nonpublic Schools.

${ }^{12}$ The next section shows empirical evidence on the relationships among Catholic population densities, subsidies to Catholic schools, Catholic school tuitions, and enrollment in Catholic schools.
} 
Table 2

\begin{tabular}{||l|c|c||}
\hline \multirow{2}{*}{ Denomination } & \multicolumn{2}{|c|}{ Percent of U.S. Private School Enrollment } \\
\cline { 2 - 3 } & Elementary & Secondary \\
\hline \hline Catholic & 78.3 & 80.2 \\
\hline Lutheran & 6.1 & 2.2 \\
\hline Jewish & 1.9 & 1.1 \\
\hline Seventh Day Adventist & 1.5 & 2.4 \\
\hline Episcopal & 1.3 & 1.1 \\
\hline Baptist & 1.3 & 1.0 \\
\hline Calvinist & 0.5 & 0.7 \\
\hline Presbyterian & 0.2 & 0.1 \\
\hline Methodist & 0.1 & 0.1 \\
\hline Friends & 0.1 & 0.1 \\
\hline Eastern Orthodox & 0.1 & 0 \\
\hline All Other Denominations & 2.5 & 1.5 \\
\hline Nonsectarian & 6.1 & 9.4 \\
\hline \hline
\end{tabular}

Catholic and Lutheran schools tend to have low tuition for private schools. In 1988, average private school tuition in the U.S. was $\$ 1.892$. Average tuition differed substantially by type of school: Catholic parochial, \$963; Catholic diocesan, $\$ 1,165$; Catholic private $\$ 3,127$; Lutheran, $\$ 1,120$; Baptist, $\$ 1,242$; Jewish, $\$ 3,175$; Episcopal, $\$ 3.536$; Friends, $\$ 4,471$; National Association of Independent Schools, $\$ 5,898 .^{13}$

There is evidence that a substantial share of parents actively compare public and private schools. In a Congressional survey of elementary and secondary school parents, $29.2 \%$ of parents actively considered both public and private schools for their children. Of these, $11.8 \%$ chose private schools and $17.4 \%$ chose public schools. Parents do not send their children to private denominational schools simply for religious reasons. If we compare nonsectarian private school

\footnotetext{
${ }^{13}$ Detailed Characteristics of Private Schools and Staffs: $1987-88$, p. 52.
} 
parents to Catholic school parents of similar income and education, the two groups are equally likely to cite academic standards and courses as the primary reason for sending their children to non-public schools (63\% of both groups cite it). This is not equally true of all religious school parents, some of whom, particularly conservative Christian (fundamentalist) parents, consciously sacrifice academic quality for religious or moral values. ${ }^{14}$

U.S. counties display considerable variation in their religious composition. See Table 3. Out of the 3,101 counties $^{15}$ in the U.S., 1,683 have populations that are less than $10 \%$ Catholic while 397 have populations that are more than $30 \%$ Catholic. 2.553 counties have populations that are less than $10 \%$ Lutheran and 147 counties have populations that are more than $30 \%$ Lutheran. The corresponding numbers are 1,776 and 540 for Baptists. Other denominations have no or very few counties with populations of which their members form at least $30 \%$. However, although they do not form a large share of the population in any county, Jews and Episcopalians densely populate certain counties in a population per square miles sense. ${ }^{16}$ See Table 4. Several denominations, then, have opportunities to form the critical masses which make providing denominational schooling easy and inexpensive. Not all denominations demonstrate interest in providing schooling: Baptist schools account for a small share of U.S. private school enrollment despite considerable population shares and population densities in many counties. Out of the denominations that have both the potential and the interest in providing schooling--Catholic,

\footnotetext{
${ }^{14}$ Private Schools in the United States: A Statistical Profile, pp. 117-124.
}

${ }^{15}$ There are 3101 counties or equivalents in the U.S. States that do not exclusively have a county system have county-equivalents created by the Bureau of the Census.

\footnotetext{
16 Throughout, I use "population share" to refer to a denomination's share of total population and "population density" to refer to a denomination's population per square mile.
} 
Lutheran, Jewish, and Episcopal--only the Catholic denomination can and does support schools almost everywhere in the U.S. ${ }^{17}$

Appendix Tables la and lb present descriptive statistics on important variables by Catholic and Lutheran population densities. In general, counties with higher Catholic population shares are more urban, have larger shares of households headed by females, and are more Hispanic. Income and the African-American population share do not have obvious relationships with the Catholic population share. ${ }^{18}$ Counties with higher Lutheran population shares, on the other hand, are less urban and more homogeneous in terms of race, income, and family composition. High population densities of Jews and Episcopalians are found only in the very urban and heterogeneous metropolitan areas of New York, Philadelphia, Washington D.C., Boston, and San Francisco.

Table 5 contains the raw correlations between the share of a county's population who adhere to a denomination and the share of county enrollment in schools affiliated with that denomination. These correlations confirm the idea that the greater is a denomination's population share in a county, the more likely is that denomination's schooling to be offered.

We expect, based on these facts, that the Catholic, Lutheran, Episcopal, and Jewish population shares and densities will provide good instruments. ${ }^{19}$ We expect Catholic variables

\footnotetext{
${ }^{17}$ Every U.S. state contains Catholic schools. Of the 1996 U.S. counties that contain at least one accredited private school, 1294 counties contain Catholic schools.

18 A few Southern states have very low Catholic population densities. These states account for the dramatic changes in the income variables and African-American population densities between counties that are $0-10 \%$ Catholic and counties that are 10-20\% Catholic. Excluding this regional effect, these variables have little correlation with the Catholic population share. The analysis controls for U.S. states to eliminate such regional effects.

${ }^{19}$ I also carried out the analysis using the population densities of every major U.S. denomination. The addition of the denominations other than the four cited adds little to the identification strategy.
} 
to provide the best instruments because (1) the fundamental relationships between population and school costs and availability are clear and (2) on the basis of observable correlations (Table la) and wide geographic distribution, we expect the Catholic variables to have the least correlation with unobservable variables that might be related to school quality.

VI.

Data

The empirical strategy outlined requires data on individuals' schooling outcomes, their backgrounds, and the characteristics of the area where they attended school. To meet these requirements, this paper combines five datasets which are matched geographically and center on the year 1980. Data on individuals are drawn from the National Longitudinal Survey of Youth (NLSY) which is a panel of 12,686 young men and women surveyed every year since 1979 . The men and women were ages 14-22 in 1979, so that the youngest members were age 25 in the last year of data used, 1990. Each individual was matched with county-level data for the county in which he or she lived at age $14 .^{20}$

Background variables drawn from the NLSY are the respondent's race, Hispanic origin, sex, and number of siblings; the educational attainment of his or her parents; the denomination of and frequency of religious attendance in the household in which he or she was raised. It is

\footnotetext{
${ }^{20}$ The NLSY asks each respondent for his place of residence at age 14. For all other relevant respondent ages (for instance, age 16), we can get residence information only for those respondents who were that age in one of the survey years. Since 7,104 respondents were age 18 or older in the first survey year, using residence information for any age other than 14 would entail dropping the majority of people in the panel. At age 14, the NLSY respondents lived in 1,296 of the 3,101 counties of the U.S.
} 
particularly important to control for the effect of the religion in which the respondent was raised. We are interested in separating the effect of living in a highly Catholic area, say, from the effect of living in a Catholic household.

The second dataset is the Survey of Church and Church Membership in the United States, 1980. This is a survey of 231,708 Judaeo-Christian congregations in the U.S., including 469 denominations and accounting for 112.5 million adherents. From this data, I derive each denomination's adherents and churches/synagogues for each of the 3,101 counties in the U.S. Denominations are aggregated, when necessary, to form major denominational categories. For instance, Reformed Jewish congregations are aggregated with Conservative Jewish congregations to form total Jewish adherents.

The third dataset is the National Center for Education Statistics (NCES) Private Schools in America survey, 1980. This is a survey of 20,050 private schools in the U.S. (about $95 \%$ of the total). For each school, the following variables are used: denominational or other affiliation, enrollment, grade levels taught, tuition, subsidies (revenue from non-tuition/non-fee sources), and geographic location.

Data on public school enrollment and public school budgets are drawn from the 1982 Census of Governments, which includes all 16,270 public school districts in the U.S. (containing more than 85,000 schools).

Finally, the 1980 census and 1983 City and County Data Book are the sources of all the county characteristics other than religious composition. In order to focus on the effects of religious composition, it is important to control for other county characteristics, such as the income distribution, that explain much of both public and private school quality. 
Appendix Table 2 contains summary statistics on all of the variables used for estimations. Observations on 10,589 of the respondents are available for estimation purposes. The other 2,097 observations are lost in the following way: ${ }^{21}$

\begin{tabular}{||c|l|}
\hline \hline Number of Observations Lost & \multicolumn{1}{c|}{ Reason for Loss } \\
\hline 973 & Missing geographic information for residence at age 14 \\
\hline 640 & Respondent did not attend public school \\
\hline 411 & Neither parent's highest grade completed was reported \\
\hline 73 & $\begin{array}{l}\text { Missing information on a county characteristic such as } \\
\text { Percent of Population Hispanic }\end{array}$ \\
\hline
\end{tabular}

\section{Results}

\section{VII.}

In the case of Catholic schools, it is possible to examine the fundamental relationships between the Catholic population and school subsidies, tuition, and enrollment. ${ }^{22}$ Tables $6 \mathrm{a}-\mathrm{c}$ contain these results. Subsidies to Catholic schools, derived from church offerings and fundraising, are shown to depend on Catholic population in Table 6a. A Catholic school's subsidies, as a percentage of income, increase by .25 percentage points for every percentage point increase in the Catholic population share of the county in which it operates. One hundred additional Catholics per square mile and an additional church per square mile increase subsidies as a percent of income by, respectively, .23 percentage points and 11 percentage points. ${ }^{23}$ These results

\footnotetext{
21 A smaller number of observations are included in wage regressions, since some individuals never have recorded wages.

${ }^{22}$ conditional on the existence of a Catholic school. Existence, subsidies, tuition, and enrollment are simultaneously determined, and it is very difficult to separately identify existence.

${ }^{23}$ Because Catholic population shares, population densities, and church densities are highly collinear, individual coeffients should be interpreted with caution.
} 
confirm the idea that Catholic schools enjoy greater subsidies in areas more heavily populated by Catholics.

Table $6 \mathrm{~b}$ analyses the dependence of Catholic school tuition on subsidies and Catholic population. When subsidies are included in the tuition equation (column 1), a Catholic school's tuition appears to depend heavily on the degree of subsidy it enjoys. Tuition per pupil falls by about $\$ 48$ for every ten percentage point increase in subsidies as a percent of income. The Catholic population appears not to affect tuition beyond its effect on subsidies. However, it is reasonable to think that not only do subsidies determine tuition, the causality generally described, but also that tuition may determine the level of subsidies received. If, for instance, a school sets very low tuition because it is located in a economically disadvantaged area, it may be able to attract more funds from the diocese and private sources. Column 2 presents reduced form results showing the dependence of tuition on Catholic population. A Catholic school's tuition falls by about $\$ 28$ for each 10 percentage point increase in the Catholic population share of the county in which it operates.

Table $6 \mathrm{c}$ shows that Catholic secondary school enrollment, as a share of county secondary school enrollment, is decreasing in the average tuition. Since tuition is potentially endogenous to enrollment, IV estimates are shown, where the identifying instrument is a school's share of teachers who contribute their services. Contributed teaching acts as a good instrument for tuition because (1) it allows a school to offer lower tuition while offering the same quantity of schooling, and (2) because the share of teachers who contribute their services is determined somewhat arbitrarily by the control of the school. In the U.S., Catholic secondary schools are under the control of several different religious orders, as well as dioceses and parishes. 
Individual orders vary in their assignment of teaching duties amongst lay and religious teachers. The IV estimated coefficient indicates that a $\$ 100$ decrease in a county's average Catholic secondary school tuition leads to a 1.4 percentage point increase in the Catholic secondary school enrollment share. The enrollment share is also increasing in the Catholic population share (a one percentage point increase in the population share raises the enrollment share by .25 percentage points) and the Catholic church density (one additional church per square mile raises the enrollment share by 21 percentage points).

Similar results for elementary school enrollment can be shown. However, an interesting by-product of this paper's analysis is that private school competition at the secondary level appears to have much stronger effects on public school students' outcomes than competition at the elementary level. For this reason, I focus on secondary school enrollment for the remainder of the analysis. ${ }^{24}$ Taken together. Tables $6 \mathrm{a}-\mathrm{c}$ confirm the idea that a more Catholic area supports schools that attract more enrollment. The greater attractiveness is partly due to lower tuition and partly due to other forces, as discussed above.

Recall the equations of interest:

$$
\begin{gathered}
y_{i j}=\gamma C_{j}+X_{j} \beta_{1}+X_{i j} \beta_{2}+\omega_{j}+\nu_{j}+\varepsilon_{i j} \\
C_{j}=R_{j} \alpha_{1}+X_{j} a_{2}+\omega_{j}+\zeta_{j} .
\end{gathered}
$$

Equation 2 is the first stage of IV estimation of equation 1, which is estimated both by feasible

\footnotetext{
${ }^{24}$ The apparent inconsequence of private school competition at the elementary level may be the result of looking at students' outcomes only at the end of their schooling paths. Ongoing work by the author examines the effect of early school quality on the schooling path.
} 
generalized least squares $(\mathrm{FGLS})^{25}$ and by IV using the vector [ $\mathbf{R} \mathbf{X}$ ] as the set of instruments.

Table 7 shows estimates of equation 2, the first-stage of the IV procedure. The share of county secondary school enrollment in Catholic schools is regressed on the Catholic population shares and densities and the Catholic church density. The estimated coefficents indicate that the Catholic school enrollment share has a very strong, positive (and quadratic) dependence on the Catholic population share and Catholic church density. Raising the Catholic population density in a county from 0 to $10 \%$ raises the Catholic secondary school enrollment share by 1.5 percentage points. The F-statistic on the excluded instruments is 28.63 , so we expect that the IV results are both unbiased and consistent if the identification strategy is appropriate. ${ }^{26}$ Note

${ }^{25}$ Recall that there are both a county-specific error term, $v_{j}$, and an individual-specific error term, $\varepsilon_{\mathrm{ij}}$. The county error term allows for omitted regressors specific to the county. Owing to this error structure, I estimate the equation by feasible generalized least squares (FGLS). The equation is also estimated by IV with county-specific and individual-specific errors. For the $n$ individual observations in county $j \in J$, the variance-covariance matrix is:

$$
\rho=\left[\begin{array}{ccccc}
\sigma_{\xi}^{2}+\sigma_{v}^{2} & \sigma_{v}^{2} & \sigma_{v}^{2} & \ldots & \sigma_{v}^{2} \\
\sigma_{v}^{2} & \sigma_{\xi}^{2}+\sigma_{v}^{2} & \sigma_{v}^{2} & \ldots & \sigma_{v}^{2} \\
& & \vdots & & \\
\sigma_{v}^{2} & \sigma_{v}^{2} & \sigma_{v}^{2} & \ldots & \sigma_{\xi}^{2}+\sigma_{v}^{2}
\end{array}\right]
$$

For FGLS, the estimators are:

$$
\partial_{v}^{2}=\frac{\sum_{t} \sum_{j}\left(e_{v}-\bar{e}_{j}\right)^{2}}{(n J-J-K)} \quad, \quad \partial_{\xi}^{2}=\frac{e^{\prime} e}{J-K}-\frac{\partial_{v}^{2}}{n}
$$

where $e_{i j}$ is the $i^{\text {th }}$ residual from a least squares dummy variables estimation of equation (1) and $e^{\prime}=$ $\left[\mathbf{e}_{11}, \ldots, \mathbf{e}_{i j}, \ldots, \mathbf{e}_{\mathrm{n}}\right]$.

${ }^{26}$ Recent papers by Nelson and Startz, Bound $e t a l$, and Staiger and Stock indicate the importance of having instruments that explain substantial variation in the endogenous explanatory variable. In finite samples, IV estimates are biased in the same direction as OLS estimates, and the magnitude of the bias approaches that of OLS estimates as the partial F-statistic between the instruments and the endogenous 
also that the Catholic secondary school enrollment share is strongly increasing the percentage of the county's population classified as urban and is decreasing in the county's Hispanic population share (controlling for the Catholic population share).

Although the Catholic population provides the best set of instruments, the Lutheran, Jewish, and Episcopalian populations also provide instruments. An alternative to predicting the Catholic secondary school enrollment share in the first stage is predicting the private school (any affiliation) enrollment share using Catholic, Lutheran, Jewish, and Episcopalian population shares, population densities, and church/synagogue densities. There is a high degree of collinearity, within a denomination, between these shares and densities. The non-Catholic denominations do not have sufficient variation to provide coefficient estimates that repay individual interpretation. The following are the partial F-statistics on the test of the hypothesis that the coefficents on a denomination's population share, square of the population share, population density, square of the population density, church density, and square of the church density are jointly zero: Catholic, $F_{6.1080}=23.71$; Lutheran, $F_{6,1080}=4.92$; Jewish, $F_{6.1080}=4.46$; Episcopalian, $F_{6,1080}=3.68$. We now have two alternative proxies for the competitiveness of private schools in a county: the Catholic enrollment share, based on the Catholic population, and the private school enrollment share, based on a wider set of instruments.

Tables 8 and 9 present the central results of the paper: estimates of how public school

explanatory variable approaches zero. Furthermore, when the instruments explain little of the variation in the endogenous explanatory variable, the conventional modeling approximations to the limiting distributions of the IV estimate and its statistics work poorly. The result is that IV estimates obtained using weakly correlated instruments are inconsistent even if only a weak relationship exists between the instruments and the error in the structural equation. Using Staiger and Stock's experimental results as a guide, the Fstatistics on the excluded instruments in the first-stage regressions presented here indicate that consistency and finite sample bias are unlikely to be problems. 
students' outcomes depend on competition from private schools. FGLS and IV results with educational attainment (highest grade completed) of public school students as the dependent variable are shown in Table $8 .^{27}$ The first and second columns show the FGLS and IV results using the Catholic secondary school enrollment share as the proxy for the competitiveness of private schools in a county. The FGLS coefficient estimate on the share of enrollment in Catholic schools is not significantly different from zero. This lack of relationship may be due to the fact that, truly, no relationship exists. Alternatively, the FGLS coefficient indicate that Catholic school enrollment reflects both increased demand for private schooling where public school quality is low and positive effects of private school competition on the way public schools operate. In contrast, the IV estimate on the percentage of enrollment in Catholic schools is positive and significantly different from zero: a change in the Catholic population of a county that translates into a 10 percentage point increase in the share of enrollment in Catholic schools produces an extra .33 years of education on average for public school students. The contrast between the FGLS and IV estimates is confirmation of the hypothesis that the IV estimate reflects only the effect of greater competition from private schools while the FGLS estimate also reflects Catholic school enrollment's negative dependence on public school quality.

The third and fourth columns of Table 8 show the FGLS and IV results using the private secondary school enrollment share as the proxy for the competitiveness of private schools in a county. The FGLS coefficient estimate on the share of enrollment in private schools is not significantly different from zero. However, the IV estimate on the percentage of enrollment in private schools indicates that a change in the Catholic, Lutheran, Jewish, and Episcopalian

\footnotetext{
${ }^{27}$ Ongoing work by the author indicates that much of the effect of school quality works through educational attainment.
} 
populations of a county that translates into a 10 percentage point increase in the share of enrollment in private schools produces an extra .35 years of education on average for public school students. The difference between the FGLS and IV estimates confirms the hypothesis that the IV estimate reflects only the competitive effect of private schools while the FGLS estimate also reflects private school enrollment's negative dependence on public school quality.

Apart from the coefficient estimates just discussed, there are several things worthy of note in Table 8. Although being schooled in a county with a high Catholic population density increases an individual's educational attainment, individuals who are raised in a Catholic household get about .21 fewer years of education on average. Being raised in a Lutheran or an Episcopalian household has no effect on educational attainment. Public school students who are raised in Jewish households, however, attain about 1 more year of education than the base group, Methodists. $^{28}$ The inclusion of these household religion indicators is important because it guarantees that the effect of higher Catholic population shares. say, does not simply reflect a tendency for higher educational attainment among Catholics. Moreover, for Catholics at least, we can dismiss the more subtle story that Catholics simply tend to get additional schooling and that they influence their neighbors of orher denominations to get additional schooling too. This story can be discounted for Lutherans and Episcopalians, but it is a possible explanation for the effect of Jewish population.

Next, note that the equation includes controls for the percentage of the population who regularly attend religious services (any denomination) and a control for the frequency of religious attendance in the household in which the individual was raised. Because the estimated effects

\footnotetext{
${ }^{28}$ Methodist households were chosen as the base group to obtain a balanced distribution around zero of the estimated coeffients on all the household religion dummies.
} 
of Catholic and private school enrollment control for these variables, we can dismiss the idea that higher denominational population shares merely reflect greater religiosity in the population, which might have a positive effect on public school students. The estimated coefficient indicates that a ten percentage point increase in the share of the population who attend services is associated with a .8 year increase in public school students' educational attainment.

The equation also includes several variables that describe the homogeneity of a county's population: Herfindahl indices of religious and racial homogeneity, and the Gini coefficient for household income. Recall that we need to control for the homogeneity of the local population, so as not to confuse the effect of greater homogeneity with the effect of private school competition. Several more possible connections between a county's character, its private school enrollment, and the educational attainment of its public school students are accounted for by the other county descriptors (income distribution, racial distribution, educational distribution, sex distribution, urbanness, and family composition) and by family background variables (parents' highest grade completed, race, sex, state of residence at age 14). ${ }^{29}$

Finally, Table 8 presents the results of testing the overidentifying restrictions in the IV equations. The restrictions are that the religious population variables do not belong in the structural equation for schooling outcomes. I use the Lagrange multiplier test, where a large value of the test statistic is taken as a rejection of the null hypothesis of exact identification--that

\footnotetext{
${ }^{29}$ Counties are described quite fully to eliminate the possibility that the coefficients on the private school enrollment shares reflect the effects of some omitted variable. The multitude of variables complicates the interpretation of certain coefficients. Of particular importance are the four income variables that describe each county's income distribution: the Gini coefficient, the shares of households with income less than $\$ 20,000$ and greater than $\$ 40,000$, and median income. The negative coefficient estimate on median income is something of a puzzle, but it becomes positive if the shares of households with income less than $\$ 20,000$ and greater than $\$ 40,000$ are dropped from the equation. Also, the coefficient estimates on the black and hispanic population shares become negative if the income variables are dropped from the equation.
} 
is, as evidence that there are exogenous variables inappropriately omitted from the structural equation. ${ }^{30}$ To the extent that public schools are affected by potential competition, religious composition has effects that work outside the proxies for private school competitiveness, which reflect only actual competition. Thus, a rejection of the null hypothesis may be evidence that potential competition is omitted from the structural equation. even if actual competition is included. Alternatively, it may be evidence that religious composition works through another channel in addition to that of private school competition.

The asymptotic test statistics for the IV equations presented in Table 7 are, respectively, $\chi^{2}=3.13$ and $\chi_{23}^{2}=4.01$. In neither case can we reject the null hypothesis that all of the effects of religious composition on educational attainment work through the proxy for private school competitiveness.

The remainder of the results presented use only the Catholic secondary school enrollment share as the proxy for private school competition. The results using the private secondary school enrollment share are similar, but interpretation of them is more complicated because Jews have above average educational attainment as individuals and because the Lutheran, Jewish, and Episcopalian population variables are somewhat region specific. The effect shown in Table 8 has more general applications than Catholic populations and Catholic schools; however, Catholics provide the most easily interpreted experiment.

Table 9 presents coefficients of interest using other student outcomes as dependent

30 The test statistic is calculated as $N R^{2}$, where $N$ is the number of observations and $R^{2}$ is the uncentered $R^{2}$ in the regression of the IV estimated residual, $\hat{Q}^{\mathrm{IV}}+\hat{\varepsilon}^{\mathrm{IV}}$, on all of the predetermined variables, [R X]. 
variables: the natural log of hourly wages on the most recent job, ${ }^{31}$ an armed forces qualifying test (AFQT) score, ${ }^{32}$ and indicators for high school graduation, two years of college (at a twoyear or four-year college), and graduation from a four-year college. As they largely confirm the results of Table 8, we need not examine them in such detail. The IV estimated coefficients in Table 9 indicate that a change in Catholic population that translates into a 10 percentage point increase in the share of enrollment in Catholic schools produces a wage increase of about $2 \%$, a 2 percentile increase in the AFQT score, a 2 percentage point increase in the probability of high school graduation by age 19 , a 3 percentage point increase in the probability of two years of college by age 24 , and a 3 percentage point increase in the probability of college graduation by age 24. As with the results of Table 8, the differences between the FGLS and IV estimates confirm the hypothesis that the IV estimates reflect only the competitive effect of private schools while the FGLS estimates also reflect the effect of public school quality on the demand for private schooling. The asymptotic $\chi^{2}$ statistics for the tests of overidentifying restrictions indicate that we cannot reject the null hypothesis that religious composition works entirely through the proxy for private school competitiveness.

Table 9a shows the effect of the Catholic secondary school enrollment share on public school teacher salaries, per-pupil spending, and per-resident spending. The IV estimated coefficients indicate that an increase in Catholic population that translates into a 10 percentage point increase in the share of enrollment in Catholic schools generates an increase of $\$ 712$ in teacher salaries, no significant change in per-pupil spending, and a decrease of $\$ 71$ in per-resident

\footnotetext{
31 This equation also includes as covariates a student's potential job market experience and experience squared.

32 This equation also includes as covariates indicators for a student's age at test-taking.
} 
spending.

\section{VIII.}

\section{What Explains These Results?}

We have determined the sign and size of the effect of private school competition on public schools. We must now consider which story best explains the results.

The teacher salary results are striking, and they naturally lead to the question of whether the salary increases of the magnitude estimated in Table 9a explain the improvement in public school students' educational attainment, wage, and probability of high school graduation. Table 10 attempts to provide evidence on this question by estimating a version of equation 1 augmented by including teacher salaries and per-pupil spending as covariates. Not only the Catholic school enrollment share but also teacher salaries and per-pupil spending are identified in these IV estimates by the denominational variables, R. Controlling for teacher salaries and per-pupil spending tends to increase the positive effect of the Catholic school enrollment share on student outcomes. $^{33}$ Table 10 shows that, exclusive of the indirect effects on salary and spending, a 10 percentage point increase in the Catholic school enrollment share generates an additional .9 years of educational attainment, $6 \%$ higher wages, and a 7 percentile increase in the AFQT score. The effects of teacher salary and per-pupil spending on student outcomes are too poorly estimated to merit discussion, but we can reject the hypothesis that the improvements in the schooling outcomes are explained by salary increases.

${ }^{33}$ The inclusion of per-pupil spending is responsible for the changes in the estimated coefficient on the Catholic school enrollment share. The inclusion of teacher salaries has no effect on the estimated coefficient. 
We also need to consider whether sorting of students between public and private schools can explain the results. Because the effect of private school competition on public schools was found to be positive, a story must be told in which private schools, when increasingly competitive, increasingly enroll students who would perform below average in the public schools. That is, any factor that lowers the cost of providing private schooling improves the student population remaining in the public schools. We can test this sorting hypothesis by estimating equation 1 by IV using both public and private school students, not allowing sorting or selection to influence the estimates. Table 11 shows IV and FGLS coefficients of interest that result from using both public and private school students' outcomes as the dependent variables. The results for public and private school students are insignificantly different from those for public school students alone. Such comparison indicates that the estimates are not influenced by the sorting of students between public and private schools. Rather, the estimates shown are consistent with religious composition both making private schools more competitive and having a positive effect on private school students.

The sorting story is unlikely for a more basic reason. Acceptance of the sorting story would constitute acceptance that private schools are extraordinarily effective. Adding an indicator variable for private school attendence to the schooling outcome equations estimated in Tables 8 and 9, and using observations on both public and private school students, we find that private school students attain an extra .8 years of education and earn a $10 \%$ higher wage. Thus, the implication of the sorting story is that Catholic schools, paying significantly lower teacher salaries and spending significantly less per pupil, receive students who would perform below average or be disruptive in the public schools and produce much better graduates than the public 
schools can produce with more promising students.

Finally, Table 12 presents results on the question of whether private school competition increases or decreases the variation of students' outcomes within a county. Increased competition from private schools may induce sorting that produces larger variation among students' outcomes (more sorting of students reduces peer effects of more able on less able students and vice versa) or sorting that produces smaller variation (more sorting permits teaching techniques to be tailored for each student, equalizing outcomes across abilities). The estimated coefficients show no evidence, perhaps because the sample size is not large, that the within-county standard deviations in educational attainment, wages. and the probability of high school graduation depend on the percentage of county secondary school enrollment in Catholic schools.

\section{IX.}

\section{Conclusions}

The results presented are evidence that increasing the potential of private schools to compete with public schools has a beneficial effect on public schooling outcomes, mostly by means that do not require higher spending. Part of the case for such an interpretation rests on our having established that Catholic, Lutheran, Jewish, and Episcopalian population densities have strong relationships with the cost and ease of providing private education. This paper offers both qualitative and empirical evidence on this point. The next part of the case rests on the central result that when these denominations' population densities act as instruments for the share of enrollment in private schools, we see that private school competition improves public school 
students' outcomes. Owing to their ubiquitousness and strong church-school connections, Catholic populations act as particularly good instruments and Catholic school enrollment acts as a particularly good proxy for private school competition. At the same time, FGLS results show us that poor public school quality may endogenously increase the share of enrollment in private schools.

A general estimate of the effect of private school competition is that a 10 percentage point increase in the share of county secondary enrollment in Catholic schools improves public school students' educational attainment by .33 years and wages by $2 \%$. Using another gauge, the same improvements in educational attainment and wages would result from a $\$ 500$ decrease in the Catholic school tuition faced by parents (without a corresponding decrease in the revenue of the schools).

I have considered several alternative explanations for the above results. A first hypothesis is that the apparent effect of the, say, Catholic population share really reflects the fact that Catholics simply have better schooling outcomes. To eliminate this story, the equations control for the religion in which the student was raised. The second hypothesis is an extension of the first: Catholics, say, not only have better schooling outcomes as individuals but also, when they form a large enough share of population, influence their non-Catholic neighbors to have better schooling outcomes. This explanation can be dismissed for Lutherans and Episcopalians, whose schooling outcomes are not better than average and can be strongly dismissed for Catholics, whose schooling outcomes are significantly worse than average. For Jews, this explanation is a possibility, as they have significantly better schooling outcomes.

A third alternative hypothesis is that apparent effects of the denominations' populations 
merely reflect positive effects of the overall religiosity of the population. Controls for frequency of religious attendance and the percentage of the county population who regularly attend religious services (any denomination) ensure that the results do not reflect this story. In addition, controls for the homogeneity of county populations (Gini coefficients for income, Herfindahl indices of racial and religious homogeneity) were included to distinguish a fourth alternative explanation: that the denominations' population densities really indicate population homogeneity that might allow public schools to function better. The results show that schooling outcomes worsen as the Herfindahl index of religious homogeneity increases. The estimates also control for many other county characteristics that might affect public school students and be correlated with religious composition.

A final alternative hypothesis is that students sort themselves between public and private schools in such a way that the private schools receive those who would perform below average or be disruptive in the public schools. However, when sorting of students between public and private school is not allowed to affect the estimates, the private school enrollment share has the same effect on student outcomes.

The one remaining hypothesis consistent with all the results is that greater private school competition improves the way public schools operate. Part of the uniqueness of this paper is that exogenous variation in private school availability and costs drives the result that public school students benefit from private schools competing with their schools. These results provide much needed evidence on the question of whether policies that increase the ability of private schools to compete with public schools will help all students--public school and private school.

However, these results are only suggestive of the effects of policies that increase the 
ability of public schools to compete with one another. The usual means by which parents transfer demand between public schools (moving house) is quite different from paying tuition and may provide different financial incentives to school personnel and different information to residents. I investigate the competition among public schools in a related paper. ${ }^{34}$

Beyond this paper, further work is needed to address certain issues relating to the interaction between public and private schools. One important issue is the effect of private school competition on classroom heterogeneity--in terms of race, ethnicity, religion, income, and ability. To the extent that classroom heterogeneity in and of itself is a social goal, private school competition may not have unambiguously positive effects. No evidence currently exists on the classroom heterogeneity effects of exogenous variation in private school competition.

34 Hoxby (1994). 


\section{Bibliography}

Aker, John S. and Irwin Garfinkel. "School Expenditures and Economic Returns to Schooling." Journal of Human Resources, Fall 1977 12(4), pp. 460-81.

Akin, J. and D Youngday. "The Efficiency of Local School Finance," Review of Economics and Statistics, 58 (1976).

Allen, Jeanne. School Choice Programs: What's Happening in the States. Washington, D.C.: The Heritage Foundation Press, 1992.

Barlow, R. "Efficiency Aspects of Local School Finance," Journal of Political Economy, 78 (1970), pp. 1028-39.

Basmann, R. "On Finite Sample Distributions of Generalized Classical Linear Identifiability Test Statistics." Journal of the American Statistical Association. Vol. 55 (1960), pp. 650-659.

Benson, Charles. The Economics of Public Education. 3rd Edition. Boston: Houghton-Mifflin, 1978.

Borland, Melvin V. and Roy M. Howsen. "Student Academic Achievement and the Degree of Market Concentration in Education." Economics of Education Review, Vol. II, No. I (1992), pp. 31-39.

Bowles, Samuel. "Towards an Education Production Function" in Education, Income, and Human Capital. ed.: W. Lee Hansen. New York: NBER, 1970. pp. 11-60.

Bound, John, David A. Jaeger, and Regina Baker. "The Cure can be Worse than the Disease: A Cautionary Tale Regarding Instrumental Variables." NBER Technical Working Paper No. 137 (June 1993).

Brueckner, J.K. "Property Values, Local Public Expenditure, and Economic Efficiency." Journal of Public Economics, 11 (1979), pp. 223-45.

---.. "Property Value Maximization and Public Sector Efficiency." Journal of Urban Economics, 14 (1983), pp. 1-16.

Buetow, Harold A. The Catholic School. New York: Crossroad, 1988.

Chubb, John E. and Terry M. Moe. Politics, Markets, and America's Schools. Washington, D.C.: The Brookings Institution, 1990.

Clune, William, and John White (eds.) Choice and Control in American Education. Vol. 2: The Practice of Choice, Decentralization, and School Restructuring. London: FalmerPress, 
1990.

Coleman, James S. and Thomas Hoffer. Public and Private High Schools. New York: Basic Books, 1987.

Coleman, James S., Thomas Hoffer, and Sally Kilgore. High School Achievement: Public, Catholic, and Private Schools Compared. New York: Basic Books, 1982.

Couch, J. F., W. F. Shughart II, and A. L. Williams. "Private School Enrollment and Public School Performance." Public Choice, (August 1993).

Courant, P.N. "A General Equilibrium Model of Heterogeneous Local Property Taxes." Journal of Public Economics, 8 (1977), pp. 313-28.

Data Research Inc. Private School Law in America. 2nd Edition. Rosemount, MN: Data Research Inc., 1989.

Downes, Thomas A. and Shane M. Greenstein. "Understanding the Supply Decisions of NonProfits: Modeling the Location of Private Schools." Northwestern University mimeo.

Dusansky, R., M. Ingbar, and N. Karatjas. "The Impact of Property Taxation on Housing Values and Rents." Journal of Urban Economics, 10 (1981), pp. 240-55.

Epple, Dennis and Richard Romano. "Competition between Private and Public Schools, Vouchers and Peer Group Effects." Carnegie Mellon University mimeo, March 1993.

Evans, William N. and Robert M. Schwab. "Finishing High School and Starting College: Do Catholic Schools Make a Difference?" University of Maryland mimeo, November 1993.

---. "Who Benefits from Private Education? Evidence from Quantile Regressions." University of Maryland mimeo, September 1993.

Foy, Felician A. (ed.) The Catholic Almanac. 1980-1992 Editions. Huntington, Indiana: Our Sunday Visitor Inc., 1980-1992.

Gaffney, Edward McGlynn Jr. (ed.) Private Schools and the Public Good. Notre Dame: University of Notre Dame Press, 1981.

Grant, Mary A. and Thomas C. Hunt. Catholic School Education in the United States. New York: Garland Publishing, Inc., 1992.

Greeley, Andrew M., William C. McCready, and Kathleen McCourt. Catholic Schools in a Declining Church. Kansas City: Sheed and Ward, Inc., 1976. 
Haertel, Edward H., Thomas James, and Henry M. Levin. Comparing Public and Private Schools. Vol. 2: School Achievement. Philadelphia: Temple University Press, 1987.

Hanline, C. Jeanne (ed.) The Official Catholic Directory 1980-1992 Editions. New Providence, New Jersey: P.J. Kenedy and Sons, A Reed Reference Publishing Co., 1980-1992.

Hanushek, Eric A. "Conceptual and Empirical Issues in the Estimation of Education Production Functions." Journal of Human Resources, Summer 1979 14(3), pp. 351-88.

---. "The Economics of Schooling: Production and Efficiency in Public Schools." Journal of Economic Literature, XXIV (Septembet 1986), pp. 1141-1177.

Hausman, J. "Specification and Estimation of Simultaneous Equation Models," in Z. Griliches and M. Intrilligator, eds., Handbook of Econometrics, Amsterdam: North Holland, 1983.

Hoxby, Caroline Minter. "Does Competition Among Public Schools Benefit Students and Taxpayers." M.I.T. mimeo, 1994.

James, Thomas and Henry M. Levin. Comparing Public and Private Schools. Vol. 1: Institutions and Organizations. Philadelphia: Temple University Press, 1987.

James, Thomas and Henry M. Levin. Public Dollars for Private Schools. Philadelphia: Temple University Press, 1983.

Kirkpatrick, David W. Choice in Schooling. Chicago: Loyala University Press, 1990.

Larson, Martin A. When Parochial Schools Close: A Study in Education Financing. Washington: Robert B. Luce, Inc. 1972.

Levy, Daniel C. (ed.) Private Education. New York: Oxford University Press, 1986.

Mickelson, Arnold R. (ed.). Where are the Lutherans? Minneapolis: Augsberg Publishing House, 1984.

Moulton, Brent R. "Random Group Effects and the Precision of Regression Estimates." Journal of Econometrics, 32 (1986), 385-97.

Murnane, Richard J. "A Review Essay - Comparisons of Public and Private Schools: Lessons from the Uproar." Journal of Human Resources 19(2) (Spring 1984), pp. 263-77.

Neal, Derek. "The Effects of Catholic Secondary Schooling on Academic Achievement and Labor Market Outcomes." University of Chicago mimeo, November 1993.

Nelson, C. R. and R. Startz. "Some Further Results on the Exact Small Sample Properties of the 
Instrumental Variables Estimator." Econometrica, Vol. 58 (1990), pp. 967-976.

----. "The Distribution of the Instrumental Variables Estimator and its t-Ratio when the Instrument is a Poor One." Journal of Business, Vol. XX (1990).

Rosen, Sherwin. "Human Capital: A Survey of Economic Research" in Research in Labor Economics, Vol. 1, ed. Ronald G. Ehrenberg. Greenwich, Conn.: JAI Press, 1977. pp. 3-39.

Staiger, Douglas and James H. Stock. "Asymptotics for Instrumental Variables Regressions with Weakly Correlated Instruments" mimeo, Kennedy School of Government, Harvard University, and the NBER (July 1993).

Sullivan, Daniel J. Public Aid to Nonpublic Schools. Lexington, MA: Lexington Books, 1974.

Summers, Anita and Barbara Wolfe. "Do Schools Make a Difference?" American Economic Review, 67(4) (September 1977), pp. 639-52.

Tiebout, C. "A Pure Theory of Local Expenditures." Journal of Political Economy, 64 (1956), pp. 416-24.

U.S. Department of Education. Office of Educational Research and Improvement. National Center for Education Statistics. Comparisons of Public and Private Schools, 1991-92. Washington, D.C.: U.S. Government Printing Office.

--.. Detailed Characteristics of Private Schools and Staff: 1987-88. Washington, D.C.: U.S. Government Printing Office.

---. Digest of Education Statistics 1991. Washington, D.C.: U.S. Government Printing Office, 1991.

---- The Private High School Today. Washington, D.C.: U.S. Government Printing Office.

----. Private Schools in the United States: A Statistical Profile, with Comparisons to Public Schools. Washington, D.C.: U.S. Government Printing Office.

----. Public and Private Elementary and Secondary Education Statistics: School Year 1991-92. Washington, D.C.: U.S. Government Printing Office.

U.S. Department of Health, Education, and Welfare. Office of Education. Helen M. Jellison, ed. State and Federal Laws Relating to Nonpublic Schools. Washington, D.C.: U.S. Government Printing Office, 1975.

West, E.G. Nonpublic School Aid. Lexington. MA: Lexington Books, 1976 
Table 1

Descriptive Statistics by Catholic Population Percentage in Diocese

\begin{tabular}{|l|c|c|c|c||}
\hline \multirow{2}{*}{} & \multicolumn{4}{|c|}{ Catholic Population Density in Diocese } \\
\cline { 2 - 6 } & $0-9 \%$ & $10-19 \%$ & $20-29 \%$ & $30 \%+$ \\
\hline \hline Parishes per Diocese & 63 & 85 & 118 & 165 \\
\hline Catholics per Parish & 1204 & 1987 & 2143 & 4250 \\
\hline $\begin{array}{l}\text { \% of Catholic School Teachers who } \\
\text { Contribute Services }\end{array}$ & 13 & 16 & 14 & 18 \\
\hline $\begin{array}{l}\text { Catholic Secondary Schools per Million } \\
\text { People }\end{array}$ & 1.8 & 5.2 & 6.3 & 8.1 \\
\hline $\begin{array}{l}\text { Catholic Secondary School Places per Million } \\
\text { People }\end{array}$ & 610 & 1742 & 2281 & 3614 \\
\hline $\begin{array}{l}\text { Catholic Elementary Schools per Million } \\
\text { People }\end{array}$ & 11.5 & 25.3 & 41.5 & 45.3 \\
\hline $\begin{array}{l}\text { Catholic Elementary School Places per } \\
\text { Million People }\end{array}$ & 2922 & 5743 & 9159 & 12307 \\
\hline Catholic Secondary Schools per Parish & .05 & .06 & .05 & .08 \\
\hline Catholic Secondary School Places per Parish & 158 & 244 & 248 & 374 \\
\hline Catholic Elementary Schools per Parish & .25 & .32 & .34 & .42 \\
\hline Catholic Elementary School Places per Parish & 61 & 80 & 90 & 129 \\
\hline Dioceses in this Category & 31 & 58 & 40 & 44 \\
\hline \hline
\end{tabular}

Source: Author's calculations based on data from The Official Catholic Directory 1980

Table 3

Number of U.S. Counties by Denominational Population Percentage

\begin{tabular}{||l|c|c|c|c|c|c||}
\hline \multirow{2}{*}{ Denomination } & \multicolumn{6}{|c||}{ \% of County Population Adhering to Denomination } \\
\cline { 2 - 8 } & $0-9$ & $10-19$ & $20-29$ & $30-39$ & $40-49$ & $50+$ \\
\hline \hline Catholic & 1683 & 668 & 353 & 191 & 93 & 113 \\
\hline Lutheran & 2553 & 253 & 148 & 71 & 53 & 23 \\
\hline Baptist & 1776 & 388 & 397 & 310 & 168 & 62 \\
\hline Episcopal & 3084 & 13 & 4 & 0 & 0 & 0 \\
\hline Jewish & 3101 & 0 & 0 & 0 & 0 & 0 \\
\hline Methodist & 1968 & 938 & 170 & 23 & 0 & 2 \\
\hline Presbyterian & 3094 & 7 & 0 & 0 & 0 & 0 \\
\hline
\end{tabular}

Note: 3101 countics

Source: Author's calculations based on data from the Survey of Churches and Church Membership. 
Table 4

Number of U.S. Counties with At Least 100 Members of Denomination Per Square Mile

\begin{tabular}{||l|c|c|}
\hline Denomination & \# of Counties & Region/State/Local Bias If Any \\
\hline \hline Catholic & 145 & \\
\hline Lutheran & 26 & Midwest, especially MN, WI \\
\hline Baptist & 50 & South, especially GA, TN, TX, KY \\
\hline Episcopal & 16 & Eastern Seaboard Cities \\
\hline Jewish & 7 & New York City Metropolitan Area \\
\hline Methodist & 25 & Ohio \\
\hline Presbyterian & 2 & Washington, D.C. \\
\hline
\end{tabular}

Note: 3101 counties

Source: Author's calculations based on data from the Survey of Churches and Church Membership.

Table 5

Raw Correlation between County Population Percentage Adhering to Denomination and Percentage of Enrollment and Schools belonging to Denomination

\begin{tabular}{||l|c|c||}
\hline Denomination & $\begin{array}{c}\text { Correlation between \% of County } \\
\text { Population Aushering to Denom. and } \\
\text { \% of Enrollment in Denom's Schools }\end{array}$ & $\begin{array}{c}\text { Correlation between \% of County } \\
\text { Population Adhering to Denom. and } \\
\text { \% of Schools Affiliated w/ Denom. }\end{array}$ \\
\hline Catholic & .6455 & .4893 \\
Lutheran & .3798 & .4394 \\
Baptist & .1570 & .1424 \\
Episcopalian & .1327 & .0567 \\
Friends & .0139 & .0203 \\
Jewish & .1459 & .2021 \\
Methodist & .0083 & .0041 \\
Presbyterian & .1073 & .1142 \\
\hline
\end{tabular}

Note: 3101 counties

Sources: Author's calculations based on data from the Survey of Churches and Church Membership and the Private Schools in America. 
Table 6a

Subsidies and Catholic Population

Dependent Variable is Subsidy as a Percentage of Catholic School Income

\begin{tabular}{|c|c|}
\hline \% of Cnty Population Catholic & $\begin{array}{l}.25 \\
(.09)\end{array}$ \\
\hline \% of Cnty Population Catholic Squared & $\begin{array}{l}-.003 \\
(.002)\end{array}$ \\
\hline Catholic Population('00s)/Sq.Mile & $\begin{array}{c}.23 \\
(.12)\end{array}$ \\
\hline Catholic Population( 00 s)/Sq.Mile Squared & $\begin{array}{c}3.1 e-5 \\
(8.3 e-6)\end{array}$ \\
\hline Catholic Churches/Sq.Mile & $\begin{array}{l}11.96 \\
(5.15)\end{array}$ \\
\hline Catholic Churches/Sq.Mile Squared & $\begin{array}{c}-.99 \\
(.90)\end{array}$ \\
\hline Middle School & $\begin{array}{l}-8.47 \\
(2.71)\end{array}$ \\
\hline Combined (K-12) School & $\begin{array}{r}-10.20 \\
(2.30)\end{array}$ \\
\hline Secondary School & $\begin{array}{c}-21.75 \\
(.90)\end{array}$ \\
\hline Constant & $\begin{array}{l}-146.02 \\
(52.73)\end{array}$ \\
\hline R-Squared & .30 \\
\hline Number of Observations & 9314 \\
\hline
\end{tabular}

OLS, standard errors in parentheses, unit of observation is a Catholic school

Notes: The dependent variable is the percentage of the Catholic school's income that comes from religious and other subsidies (mean 35, standard deviation 30). Covariates not shown are:

o school: dummy variables for all boys, all girls, all students board, some students board, school has special program in addition to regular elementary and secondary education

O county: median income; Gini coefficient on household income; racial and religious Herfindahl indices; percentages of population that are urban, are AfricanAmerican, are Hispanic, are Male, have at least 12 years of education, have at least 16 years of education, and regularly attend religious services; percentages of households that are headed by females, have less than $\$ 20,000$ in income, and have more than $\$ 40,000$ in income. 
Table 6b

Subsidies and Tuition

Dependent Variable is Tuition per Pupil of Catholic Schools

\begin{tabular}{||lcc||}
\hline Subsidy as a Share of Income & -4.76 & \\
\% of Cnty Population Catholic & $(.19)$ & \\
& -2.11 & -3.31 \\
\% of Cnty Population Catholic Squared & $(1.68)$ & $(1.24)$ \\
& .03 & .05 \\
Catholic Population('00s)/Sq.Mile & $(.04)$ & $(.04)$ \\
& -1.09 & -2.19 \\
Catholic Population('00s)/Sq.Mile Squared & $(2.32)$ & $(2.40)$ \\
& $8.4 \mathrm{e}-4$ & $1.6 \mathrm{e}-2$ \\
Catholic Churches/Sq.Mile & $(1.5 \mathrm{e}-2)$ & $(1.6 \mathrm{e}-2)$ \\
& 87.83 & 35.33 \\
Catholic Churches/Sq.Mile Squared & $(93.94)$ & $(97.05)$ \\
& -4.78 & -.14 \\
Percent of Catholic School Teachers who & $(16.58)$ & $(17.13)$ \\
Contribute their Services & -2.59 & -2.48 \\
Middle School & $(.28)$ & $(.29)$ \\
& 92.88 & 133.09 \\
Combined (K-12) School & $(49.51)$ & $(51.14)$ \\
& 198.65 & 247.84 \\
Secondary School & $(42.03)$ & $(43.39)$ \\
& 256.39 & 360.01 \\
Constant & $(16.85)$ & $(16.88)$ \\
R-Squared & -385.78 & 284.48 \\
Number of Observations & $(963.83)$ & $(995.67)$ \\
\hline
\end{tabular}

OLS, standard errors in parentheses, unit of observation is a Catholic school

Notes: The dependent variable is the per pupil tuition of a Catholic school 1979\$ (actual tuition revenue divided by the number of students, generally lower than the "list tuition") (mean \$358, standard deviation \$615). Covariates not shown are:

O school: dummy variables for all boys, all girls, all students board, some students board, school has special program in addition to regular elementary and secondary education

o county: median income; Gini coefficient on household income; racial and religious Herfindahl indices; percentages of population that are urban, are AfricanAmerican, are Hispanic, are Male, have at least 12 years of education, have at least 16 years of education, and regularly attend religious services; percentages of households that are headed by females, have less than $\$ 20,000$ in income, and have more than $\$ 40,000$ in income. 


\section{Table 6e}

Tuition and Enrollment

Dependent Variable is Percentage of County Secondary School Enrollment in Catholic Schools IV Estimates"

\begin{tabular}{||cc||}
\hline County Avg. Tuition in Catholic & -1.4 \\
Secondary Schools ('00s) & $(.6)$ \\
\% of Cnty Population Catholic & .25 \\
& $(.11)$ \\
\% of Cnty Population Catholic Squared & $-3.3 \mathrm{e}-3$ \\
& $(2.9 \mathrm{e}-3)$ \\
Catholic Population('00s)/Sq.Mile & -.22 \\
& $(.26)$ \\
Catholic Population('00s)/Sq.Mile Squared & $5.8 \mathrm{e}-4$ \\
& $(1.8 \mathrm{e}-3)$ \\
Catholic Churches/Sq.Mile & 24.84 \\
& $(10.59)$ \\
Catholic Churches/Sq.Mile Squared & -3.75 \\
& $(1.85)$ \\
Percent of County Population Urban & .08 \\
& $(.03)$ \\
Constant & 38.83 \\
& $(144.88)$ \\
F-Statistic all Coefficients & 6.74 \\
(Prob > F) & $(.0000)$ \\
Number of Observations & 484 \\
\hline
\end{tabular}

IV, standard errors in parentheses, unit of observation is a county

- The excluded exogenous variable that identifies tuition is the share of Catholic secondary school teachers in the county who contribute their services). For comparison, the OLS coefficient on tuition is -.0004 $(.0008)$.

Notes: The dependent variable is the percentage of county secondary school enrollment in Catholic schools (mean 7.6, standard deviation 5.1). Covariates not shown are:

o county: median income; Gini coefficient on household income; racial and religious Herfindahl indices; percentages of population that are urban, are Hispanic, are Male, have at least 12 years of education, have at least 16 years of education, and regularly attend religious services; percentages of households that are headed by females, have less than $\$ 20,000$ in income, and have more than $\$ 40,000$ in income. 
Table 7

Catholic School Enrollment and Catholic Population (1st-Stage OLS Regression) Dependent Variable is the Percentage of County Secondary School Enrollment in Catholic Schools

\begin{tabular}{||lc||}
\hline \% of Cnty Population Catholic & $\mathbf{. 1 6}$ \\
\% of Cnty Population Catholic Squared & $\mathbf{( . 0 2 )}$ \\
& $\mathbf{- 1 . 1 e - 3}$ \\
Catholic Population('00s)/Sq.Mile & $\mathbf{( 2 . 3 e - 4 )}$ \\
& $\mathbf{. 4 6}$ \\
Catholic Population('00s)/Sq.Mile Squared & $\mathbf{( . 4 1 )}$ \\
& $\mathbf{. 0 7}$ \\
Catholic Churches/Sq.Mile & $\mathbf{( . 0 7 )}$ \\
& $\mathbf{1 0 6}$ \\
Catholic Churches/Sq.Mile Squared & $\mathbf{( 1 9 )}$ \\
& $\mathbf{- 2 2}$ \\
Percent of County Population Urban & $\mathbf{7 8 )}$ \\
& .02 \\
Percent of County Households with Female Head & $(.01)$ \\
Racial Homogeneity Herfindahl Index & .30 \\
& $(.10)$ \\
Percent of County Population African-American & .01 \\
& $(.01)$ \\
Percent of County Population Hispanic & -.04 \\
& $(.02)$ \\
Gini Coefficient for County Household Incomes & -.08 \\
& $(.02)$ \\
Per Capita Income in County ('Oo0s) & 6.18 \\
& $(8.92)$ \\
Religious Homogeneity Herfindahl Index & .16 \\
Percent of County Population Regularly Attends Religious & $(.07)$ \\
Services (Any Denomination) & -29.16 \\
State Indicator Variables & $(15.84)$ \\
Number of Observations & .06 \\
F-Statistic on Excluded Instruments & yes \\
(Prob > F) & 947 \\
\hline
\end{tabular}

OLS, standard errors in parentheses, unit of observation is a county

Notes: The dependent variable is the share of county secondary school enrollment in Catholic schools (mean 7.6, standard deviation 5.1). Covariates not shown are:

O county: percentages of county population that are Male, Asian, Native American, have at least 12 or 16 years of education; Herfindahl index of public school concentration; land area (and its square); population; population density; percentages of households that receive transfer payments, are below the poverty level, have less than $\$ 10,000$ income, have $\$ 10,000-20,000$ income,..., have more than $\$ 50,000$ income;

See text for partial F-statistics in the alternative first stage regression (Catholic, Lutheran, Jewish and Episcopalian variables used as instruments for the share of cnty sec. school enrollment in private schools). 
Table 8

Public Schooling Outcomes and Private School Enrollment

Dependent Variable is Highest Grade Completed by Age 24

\begin{tabular}{|c|c|c|c|c|}
\hline & OLS & $\begin{array}{c}\text { IV } \\
\text { Ident. Instrumts: } \\
\text { Catholic Pop. } \\
\text { Shares \& Densities. } \\
\text { Church Densities }\end{array}$ & OLS & $\begin{array}{c}\text { IV } \\
\text { Ident. Instrumts: } \\
\text { Cathlc, Luthrn, Jewish, } \\
\text { Episcopaln Pop. Shares \& } \\
\text { Densities, Church Dens. }\end{array}$ \\
\hline \begin{tabular}{|l|} 
\% Cnty Secondary School \\
Enrollment in Catholic Schools
\end{tabular} & $\begin{array}{l}-.01 \\
(.01)\end{array}$ & $\begin{array}{l}.033 \\
(.012)\end{array}$ & & \\
\hline $\begin{array}{l}\text { \% Cnty Secondary School } \\
\text { Enrollment in Private Schools }\end{array}$ & & & $\begin{array}{c}.01 \\
(.01)\end{array}$ & $\begin{array}{l}.035 \\
(.014)\end{array}$ \\
\hline $\begin{array}{l}\text { Religious Homogeneity } \\
\text { Index }\end{array}$ & $\begin{array}{l}-.90 \\
(.46)\end{array}$ & $\begin{array}{l}-.88 \\
(.46)\end{array}$ & $\begin{array}{l}-1.00 \\
(.45)\end{array}$ & $\begin{array}{c}-96 \\
(.45)\end{array}$ \\
\hline $\begin{array}{l}\text { Percent of County Pop. Regularly } \\
\text { Attend Relig. Serv. }\end{array}$ & $\begin{array}{c}.65 \\
(.34)\end{array}$ & $\begin{array}{l}.80 \\
(.36)\end{array}$ & $\begin{array}{l}.85 \\
(.33)\end{array}$ & $\begin{array}{l}.88 \\
(.33)\end{array}$ \\
\hline Raised in Catholic Household & $\begin{array}{l}-.21 \\
(.07)\end{array}$ & $\begin{array}{l}-.21 \\
(.07)\end{array}$ & $\begin{array}{l}-.18 \\
(.07)\end{array}$ & $\begin{array}{l}-.18 \\
(.07)\end{array}$ \\
\hline Raised in Lutheran Household & $\begin{array}{l}.01 \\
(.10)\end{array}$ & $\begin{array}{l}.01 \\
(.10)\end{array}$ & $\begin{array}{l}.01 \\
(.10)\end{array}$ & $\begin{array}{l}.01 \\
(.10)\end{array}$ \\
\hline Raised in Jewish Household & $\begin{array}{l}1.05 \\
(.20)\end{array}$ & $\begin{array}{l}1.07 \\
(.20)\end{array}$ & $\begin{array}{l}1.05 \\
(.20)\end{array}$ & $\begin{array}{l}1.06 \\
(.20)\end{array}$ \\
\hline Raised in Episcopalian Househld & $\begin{array}{l}.23 \\
(.16)\end{array}$ & $\begin{array}{l}.23 \\
(.16)\end{array}$ & $\begin{array}{l}.22 \\
(.15)\end{array}$ & $\begin{array}{l}.21 \\
(.15)\end{array}$ \\
\hline $\begin{array}{l}\text { Frequency of Religious } \\
\text { Attendance (Househd Raised in) }\end{array}$ & $\begin{array}{l}.21 \\
(.01)\end{array}$ & $\begin{array}{l}.21 \\
(.01)\end{array}$ & $\begin{array}{l}.21 \\
(.01)\end{array}$ & $\begin{array}{l}.21 \\
(.01)\end{array}$ \\
\hline $\begin{array}{l}\text { \% Cnty Population } \\
\text { Urban }\end{array}$ & $\begin{array}{l}.003 \\
(.002)\end{array}$ & $\begin{array}{l}.004 \\
(.002)\end{array}$ & $\begin{array}{l}.002 \\
(.002)\end{array}$ & $\begin{array}{l}.003 \\
(.002)\end{array}$ \\
\hline $\begin{array}{l}\% \text { Cnty Households } \\
\text { w/ Female Head }\end{array}$ & $\begin{array}{l}-.06 \\
(.03)\end{array}$ & $\begin{array}{l}-.04 \\
(.03)\end{array}$ & $\begin{array}{l}-.06 \\
(.03)\end{array}$ & $\begin{array}{l}-.06 \\
(.03)\end{array}$ \\
\hline $\begin{array}{l}\text { Racial Homogeneity } \\
\text { Index }\end{array}$ & $\begin{array}{l}.02 \\
(.55)\end{array}$ & $\begin{array}{l}-.04 \\
(.55)\end{array}$ & $\begin{array}{l}-.01 \\
(.54)\end{array}$ & $\begin{array}{l}.01 \\
(.54)\end{array}$ \\
\hline $\begin{array}{l}\% \text { Cnty Population } \\
\text { African-American }\end{array}$ & $\begin{array}{l}.008 \\
(.008)\end{array}$ & $\begin{array}{l}.007 \\
(.008)\end{array}$ & $\begin{array}{l}.008 \\
(.008)\end{array}$ & $\begin{array}{l}.012 \\
(.008)\end{array}$ \\
\hline $\begin{array}{l}\text { \% Cnty Population } \\
\text { Hispanic }\end{array}$ & $\begin{array}{l}.023 \\
(.005)\end{array}$ & $\begin{array}{l}.022 \\
(.005)\end{array}$ & $\begin{array}{c}.020 \\
(.005)\end{array}$ & $\begin{array}{l}.021 \\
(.005)\end{array}$ \\
\hline $\begin{array}{l}\text { Gini Coefficient for } \\
\text { Cnty Househld Income }\end{array}$ & $\begin{array}{l}-5.44 \\
(2.84)\end{array}$ & $\begin{array}{l}-5.98 \\
(2.86)\end{array}$ & $\begin{array}{l}-5.09 \\
(2.79)\end{array}$ & $\begin{array}{l}-4.41 \\
(2.81)\end{array}$ \\
\hline $\begin{array}{l}\text { Per Capita Income in } \\
\text { Cnty/1000 }\end{array}$ & $\begin{array}{l}.06 \\
(.03)\end{array}$ & $\begin{array}{l}.07 \\
(.03)\end{array}$ & $\begin{array}{l}.06 \\
(.03)\end{array}$ & $\begin{array}{l}.07 \\
(.03)\end{array}$ \\
\hline State Indicator Variables & yes & yes & yes & yes \\
\hline No. of Observations & 10589 & 10589 & 10589 & 10589 \\
\hline $\begin{array}{l}\chi^{2} \text { on Test of Overidentifying } \\
\text { Restrictns (Asymp.Prob }>\chi^{2} \text { ) }\end{array}$ & & $\begin{aligned} & \chi_{5}^{2}=3.13 \\
&(.40)\end{aligned}$ & & $\begin{array}{c}\chi_{23}^{2}=4.01 \\
(.45)\end{array}$ \\
\hline
\end{tabular}

FGLS and IV, standard errors in parentheses, unit of observation is a public school student

Notes: Dependent var, is highest grade completed by age 24 (mean 12.3, standard deviation 2.2). Covariates not shown:

O individual: parents' highest grade completed; number of siblings; African-American, Hispanic, female, other household denominations (Baptist, Presbyterian, Conserv. Christian, other religion, no religion)

- county: $\quad$ percentages of county population Male, Asian, Native American, have at least 12 or 16 years of education; Herfindahl index of public schl conc.: land area (and its square); population; population density: percentages of households that receive transfer payments, are below the poverty level, have less than $\$ 10,000$ income, have $\$ 10,000-20,000$ income..., have more than $\$ 50,000$ income; 
Table 9

More Public Schooling Outcomes and Private School Enrollment

Est. Coefficients on the \% of Cnty/SMSA Secondary School Enrollment in Catholic Schools

\begin{tabular}{|c|ccccc||}
\hline \multirow{2}{*}{} & \multicolumn{5}{|c|}{ Dependent Variable } \\
\cline { 2 - 7 } & $\begin{array}{c}\text { Ln(Hourly Wage } \\
\text { at Age 24) }\end{array}$ & $\begin{array}{c}\text { AFQT \%ile } \\
\text { Score }\end{array}$ & $\begin{array}{c}\text { High School } \\
\text { Diploma by } \\
\text { Age 19 }\end{array}$ & $\begin{array}{c}\text { 2 Years of } \\
\text { College by } \\
\text { Age 24 }\end{array}$ & $\begin{array}{c}\text { Grad. 4-Year } \\
\text { College by } \\
\text { Age 24 }\end{array}$ \\
\hline IV coefficient estimate & .0019 & .19 & .002 & .003 & .003 \\
& $(.0006)$ & $(.09)$ & $(.001)$ & $(.001)$ & $(.001)$ \\
FGLS coefficient estimate & .0002 & -.08 & -.0005 & .003 & .004 \\
& $(.0002)$ & $(.06)$ & $(.0004)$ & $(.001)$ & $(.001)$ \\
\hline$\chi^{2}$ Test of Overidentifying & $\chi^{2}{ }_{s}=2.01$ & $\chi^{2}{ }_{s}=4.59$ & $\chi^{2}{ }_{s}=5.34$ & $\chi^{2}{ }_{s}=4.38$ & $\chi^{2}{ }_{s}=2.61$ \\
Restrictns (A.Prob $\left.>\chi^{2}\right)$ & $(.25)$ & $(.50)$ & $(.60)$ & $(.50)$ & $(.25)$ \\
\hline No. Observations & 7882 & 10164 & 10589 & 10589 & 10589 \\
Unit of Observation & Pub Sch Student & $\begin{array}{c}\text { Pub Sch } \\
\text { Student }\end{array}$ & $\begin{array}{c}\text { Pub Sch } \\
\text { Student }\end{array}$ & $\begin{array}{c}\text { Pub Sch } \\
\text { Student }\end{array}$ & $\begin{array}{c}\text { Pub Sch } \\
\text { Student }\end{array}$ \\
\hline \hline
\end{tabular}

IV and FGLS, standard errors in parentheses, unit of observation is a public school student. Estimated equations have same covariates as eqns. in Table 8, except that the wage eqn. also includes potential experience (and its square) and the AFQT score eqn. also includes indicators for age at test-taking.

Ln(Hourly Wage at Age 24) has mean 1.96, standard deviation .48 (1990 \$). AFQT Percentile Score has mean 40.9, standard deviation 28.7. Indicator for High School Diploma by Age 19 has mean .71, standard deviation .45. Indicator for Two Years of College by Age 24 has mean .25, standard deviation .43

Table 9a

Public School Characteristics and Private School Enrollment

Est. Coefficients on the \% of Cnty/SMS A Secondary School Enrollment in Catholic Schools

\begin{tabular}{|c|ccc||}
\hline & \multicolumn{3}{|c|}{ Dependent Variable } \\
\cline { 2 - 5 } & $\begin{array}{c}\text { Starting Salary } \\
\text { for Teacher } \\
\text { with a B.A. }\end{array}$ & $\begin{array}{c}\text { County/SMSA } \\
\text { Avg Per-Pupil } \\
\text { Spending in } \\
\text { Pub Schools }\end{array}$ & $\begin{array}{c}\text { County/SMSA Avg } \\
\text { Per-Resident } \\
\text { Spending in } \\
\text { Pub Schools }\end{array}$ \\
\hline IV coefficient estimate & 71.20 & -18.77 & -7.12 \\
& $(11.15)$ & $(15.11)$ & $(2.79)$ \\
FGLS coefficient estimate & -.40 & -2.91 & -2.46 \\
& $(5.22)$ & $(6.35)$ & $(1.17)$ \\
\hline$\chi^{2}$ Test of Overidentifying & $\chi^{2}{ }_{s}=6.58$ & $\chi^{2}=2.19$ & $\chi^{2}{ }_{s}=4.89$ \\
Restrictns (A.Prob $\left.>\chi^{2}\right)$ & $(.75)$ & $(.20)$ & $(.55)$ \\
\hline No. Observations & 1093 & 947 & 947 \\
Unit of Observation & Public School & County/SMSA & County/SMSA \\
\hline
\end{tabular}

IV and FGLS, std errors in parentheses. Estimated equations have same covariates as eqns. in Table 8.

Starting Salary for Teacher with a B.A. has mean $\$ 10,785$, standard deviation $\$ 1,142$ (1980\$)

County Avg Per-Pupil Spending in Public Schools has mean \$2,199, standard deviation \$517 (1980\$) 
Table 10

Does the Private School Effect Work through Public School Spending?

Est. Coefficients on the \% of Cnty/SMSA Secondary School Enrollment in Catholic Schools, Starting Teacher Salary, and Cnty/SMSA Avg Per-Pupil Spending in the Public Schools

\begin{tabular}{|c|ccc||}
\hline & \multicolumn{3}{|c|}{ Dependent Variable in IV Equation } \\
\cline { 2 - 4 } & $\begin{array}{c}\text { Highest Grade } \\
\text { Cmpitd }\end{array}$ & Ln(Hrly Wage) & AFQT \%ile Score \\
\hline $\begin{array}{c}\text { \% of Cnty/SMSA Secondary School } \\
\text { Enrollment in Catholic Schools }\end{array}$ & .09 & .06 & .67 \\
Starting Salary for Teacher with a & .18 & $(.01)$ & $(.23)$ \\
B.A. (in Public Schools) in thousands & $(.21)$ & .09 & .60 \\
Cnty/SMSA Avg Per-Pupil Spending & 1.37 & $(.08)$ & $(2.70)$ \\
in the Public Schools in thousands & $(.73)$ & .16 & 8.44 \\
\hline No. of Observations & 10589 & $(.19)$ & $(9.03)$ \\
Unit of Observation & Pub Sch Student & Pub Sch Student & Pub Sch Student \\
\hline
\end{tabular}

IV, standard errors in parentheses, unit of observation is a public school student. Estimated equations have same covariates as equations in Table 8, except that starting teacher salary and per-pupil spending are also included.

Table 11

Sorting? Public and Private Schooling Outcomes

Est. Coefficients on the \% of County/SMSA Secondary School Enrollment in Catholic Schools with Public and Private School Students' Outcomes

\begin{tabular}{|c|ccc||}
\hline & \multicolumn{3}{|c|}{ Dependent Variable in IV Equation } \\
\cline { 2 - 4 } & $\begin{array}{c}\text { Highest Grade } \\
\text { Cmpltd }\end{array}$ & Ln(Hrly Wage) & AFQT \%ile Score \\
\hline IV Coefficient Estimate & .039 & .0028 & .29 \\
& $(.037)$ & $(.0006)$ & $(.13)$ \\
FGLS Coefficient Estimate & .01 & .0003 & .16 \\
& $(.01)$ & $(.0004)$ & $(.10)$ \\
\hline No. of Observations & 11229 & 8442 & 10797 \\
Unit of Observation & Pub \& Prv Students & Pub \& Prv Students & Pub \& Prv Students \\
\hline
\end{tabular}

IV and FGLS, standard errors in parentheses, unit of observation is a public or private school student. Estimated equations have same covariates as equations in Tables 8 and 9, but they use observations on private as well as public school students. 
Table 12

The Variation of Schooling Outcomes (Public and Private) and Private School Enrollment

Est. Coefficients on the \% of County/SMSA Secondary School Enrollment in Catholic Schools Dependent Var is Within-County/SMSA Std Dev of Schooling Outcomes (Public \& Private)

\begin{tabular}{|c|c|c|c|}
\hline & \multicolumn{3}{|c|}{ Dependent Variable in IV Equation } \\
\hline & $\begin{array}{c}\text { Within-Cnty/SMSA } \\
\text { Std. Dev. of } \\
\text { Highest Grade } \\
\text { Completed }\end{array}$ & $\begin{array}{c}\text { Within-Cnty/SMSA } \\
\text { Std. Dev. of } \\
\text { Ln(Hourly } \\
\text { Wage) }\end{array}$ & $\begin{array}{c}\text { Within-Cnty/SMSA } \\
\text { Std. Dev. of } \\
\text { AFQT \%ile Score }\end{array}$ \\
\hline $\begin{array}{l}\text { \% Cnty/SMSA Secondary Sch } \\
\text { Enrollmt in Catholic Schls }\end{array}$ & $\begin{array}{l}.036 \\
(.040)\end{array}$ & $\begin{array}{l}.004 \\
(.010)\end{array}$ & $\begin{array}{c}1.64 \\
(5.18)\end{array}$ \\
\hline No. of Observations & 947 & 789 & 947 \\
\hline Unit of Observation & Cnty/SMSA & Cnty/SMSA & Cnty/SMSA \\
\hline
\end{tabular}

IV, standard errors in parentheses, unit of observation is a county. Estimated equations have same county level covariates as equations in Table 8. Catholic population shares and densities and church densities are the identifying instruments. 
Appendix Table 1a

Selected Variables by \% of the County Population who are Catholic

\begin{tabular}{|c|c|c|c|c|}
\hline & \multicolumn{4}{|c|}{$\%$ of County Population Catholic } \\
\hline & $0-10 \%$ & $10-20 \%$ & $20-30 \%$ & $30 \%+$ \\
\hline Highest Grade Completed by Age 24 & $\begin{array}{l}12.29 \\
(2.23)\end{array}$ & $\begin{array}{l}12.36 \\
(2.13)\end{array}$ & $\begin{array}{l}12.43 \\
(2.07)\end{array}$ & $\begin{array}{l}12.54^{* \prime \prime} \\
(2.23)\end{array}$ \\
\hline Ln(Hourly Wage at Age 24 1990\$) & $\begin{array}{l}1.89^{* *} \\
(.47)\end{array}$ & $\begin{array}{l}1.96 \\
(.49)\end{array}$ & $\begin{array}{l}1.98^{*} \\
(.50)\end{array}$ & $\begin{array}{l}2.01^{* *} \\
(.48)\end{array}$ \\
\hline High School Graduate by Age 19? & $\begin{array}{l}.70 \\
(.46)\end{array}$ & $\begin{array}{l}.71 \\
(.46)\end{array}$ & $\begin{array}{l}.72 \\
(.50)\end{array}$ & $\begin{array}{l}.72^{\prime \prime} \\
(.45)\end{array}$ \\
\hline $\begin{array}{l}\text { Starting Salary of Public School Teacher with a } \\
\text { B.A. }\end{array}$ & $\begin{array}{l}10544 \\
(1004)\end{array}$ & $\begin{array}{l}11068^{* *} \\
(1013)\end{array}$ & $\begin{array}{l}11196^{* *} \\
(1319)\end{array}$ & $\begin{array}{l}10937^{* \prime \prime} \\
(1166)\end{array}$ \\
\hline County Per-Pupil Spending in Public Schools & $\begin{array}{l}1319^{* *} \\
(401)\end{array}$ & $\begin{array}{l}1719^{* *} \\
(415)\end{array}$ & $\begin{array}{l}1685^{\circ} \\
(428)\end{array}$ & $\begin{array}{c}1855^{\prime \prime \prime} \\
(904)\end{array}$ \\
\hline$\%$ of County Enrollment in Private Schools & $\begin{array}{l}7.2^{\circ *} \\
(5.4)\end{array}$ & $\begin{array}{l}8.3^{* *} \\
(3.6)\end{array}$ & $\begin{array}{l}11.3^{\circ *} \\
(6.1)\end{array}$ & $\begin{array}{l}15.9^{\prime \prime \prime} \\
(7.1)\end{array}$ \\
\hline$\%$ of County Population Urban & $\begin{array}{l}54.7^{-*} \\
(29.4)\end{array}$ & $\begin{array}{l}74.6^{-=} \\
(25.8)\end{array}$ & $\begin{array}{l}81.7^{* *} \\
(23.7)\end{array}$ & $\begin{array}{l}83.9^{\prime \prime \prime} \\
(20.2)\end{array}$ \\
\hline$\%$ of County Households w/ Female Head & $\begin{array}{l}14.0 \\
(4.4)\end{array}$ & $\begin{array}{l}14.0^{* *} \\
(6.0)\end{array}$ & $\begin{array}{l}15.3^{* *} \\
(5.4)\end{array}$ & $\begin{array}{l}16.6^{* *} \\
(6.5)\end{array}$ \\
\hline Racial Homogeneity Index & $\begin{array}{c}.71 \\
(.17)\end{array}$ & $\begin{array}{l}.71^{* *} \\
(.16)\end{array}$ & $\begin{array}{l}.62^{\circ-} \\
(.23)\end{array}$ & $\begin{array}{l}.70^{\circ \prime \prime} \\
(.20)\end{array}$ \\
\hline$\%$ of County Population African-American & $\begin{array}{l}17.5^{\circ *} \\
(15.8)\end{array}$ & $\begin{array}{l}10.2^{* *} \\
(15.7)\end{array}$ & $\begin{array}{l}11.4^{* *} \\
(11.5)\end{array}$ & $\begin{array}{l}12.6^{\prime \prime \prime} \\
(13.0)\end{array}$ \\
\hline$\%$ of County Population Hispanic & $\begin{array}{l}1.9^{* *} \\
(2.7)\end{array}$ & $\begin{array}{l}7.5^{\circ .} \\
(8.3)\end{array}$ & $\begin{array}{l}15.4^{* *} \\
(17.5)\end{array}$ & $\begin{array}{l}10.2^{* *} \\
(17.8)\end{array}$ \\
\hline Gini Coefficient on Household Income & $\begin{array}{l}.40^{* *} \\
(.02)\end{array}$ & $\begin{array}{l}.39^{* *} \\
(.02)\end{array}$ & $\begin{array}{c}.40 \\
(.03)\end{array}$ & $\begin{array}{l}.40^{\prime \prime \prime} \\
(.03)\end{array}$ \\
\hline $\begin{array}{l}\% \text { of County Households with Income Less } \\
\text { than } \$ 20,000\end{array}$ & $\begin{array}{l}67.1^{* *} \\
(7.7)\end{array}$ & $\begin{array}{l}57.2 \\
(8.8)\end{array}$ & $\begin{array}{l}57.3 \\
(8.8)\end{array}$ & $\begin{array}{l}57.2^{n *} \\
(11.8)\end{array}$ \\
\hline County Median Income & $\begin{array}{l}14337^{* *} \\
(2523)\end{array}$ & $\begin{array}{r}17544 \\
(3008)\end{array}$ & $\begin{array}{l}17370 \\
(3006)\end{array}$ & $\begin{array}{l}17534^{* \prime \prime} \\
(4095)\end{array}$ \\
\hline $\begin{array}{l}\% \text { of County Households with Income Greater } \\
\text { than } \$ 40,000\end{array}$ & $\begin{array}{l}5.9^{* *} \\
(2.8)\end{array}$ & $\begin{array}{l}9.2^{-*} \\
(4.1)\end{array}$ & $\begin{array}{c}9.6 \\
(3.6)\end{array}$ & $\begin{array}{l}9.8^{n+1} \\
(5.1)\end{array}$ \\
\hline Religious Homogeneity Index & $\begin{array}{l}.08^{*-} \\
(.08)\end{array}$ & $\begin{array}{l}.04^{* *} \\
(.03)\end{array}$ & $\begin{array}{l}.08^{* *} \\
(.04)\end{array}$ & $\begin{array}{l}.20^{\prime \prime \prime} \\
(.11)\end{array}$ \\
\hline
\end{tabular}

${ }^{*}\left({ }^{* *}\right)$ indicates the mean is different from the mean in the next highest catagory at a .05 (.01) level.

\# (\#\#) indicates that the mean in the highest catagory is different from the mean in the lowest catagory at a $.05(.01)$ level.

Standard deviations in parenthesis. Cell sizes are 3488, 2118, 1988, and 2995 for all variables except ln(bourly wage) and starting salary of public school teacher with a B.A., both of which have fewer observations in each cell. 
Appendix Table 1b

Selected Variables by \% of the County Population who are Lutheran

\begin{tabular}{|c|c|c|c|c|}
\hline & \multicolumn{4}{|c|}{$\%$ of County Population Lutheran } \\
\hline & $0-2 \%$ & $2-5 \%$ & $5-15 \%$ & $15 \%+$ \\
\hline Highest Grade Completed by Age 24 & $\begin{array}{l}12.29^{* *} \\
(2.19)\end{array}$ & $\begin{array}{l}12.43^{* *} \\
(2.18)\end{array}$ & $\begin{array}{l}12.65 \\
(2.20)\end{array}$ & $\begin{array}{l}12.82^{m i n} \\
(2.04)\end{array}$ \\
\hline Ln(Hourly Wage at Age 24 1990\$) & $\begin{array}{l}1.94^{* *} \\
(.48)\end{array}$ & $\begin{array}{l}1.97 \\
(.48)\end{array}$ & $\begin{array}{l}1.97 \\
(.51)\end{array}$ & $\begin{array}{c}2.00^{\circ *} \\
(.48)\end{array}$ \\
\hline High School Graduate by Age 19 ? & $\begin{array}{l}.68^{\circ *} \\
(.47)\end{array}$ & $\begin{array}{l}.72 * \\
(.45)\end{array}$ & $\begin{array}{l}.78^{* *} \\
(.42)\end{array}$ & $\begin{array}{l}.84^{\prime \prime \prime} \\
(.36)\end{array}$ \\
\hline $\begin{array}{l}\text { Starting Salary of Public School Teacher with a } \\
\text { B.A. }\end{array}$ & $\begin{array}{l}10795^{* *} \\
(1139)\end{array}$ & $\begin{array}{l}11270^{* *} \\
(1278)\end{array}$ & $\begin{array}{l}10621 \\
(818)\end{array}$ & $\begin{array}{c}10547^{\prime \prime \prime} \\
(732)\end{array}$ \\
\hline County Per-Pupil Spending in Public Schools & $\begin{array}{c}1571^{* *} \\
(771)\end{array}$ & $\begin{array}{l}1702^{*} \\
(420)\end{array}$ & $\begin{array}{l}1608^{* *} \\
(325)\end{array}$ & $\begin{array}{l}1714^{\prime \prime \prime} \\
(308)\end{array}$ \\
\hline$\%$ of County Enrollment in Private Schools & $\begin{array}{l}10.4^{* \bullet} \\
(7.2)\end{array}$ & $\begin{array}{l}11.3^{* *} \\
(5.9)\end{array}$ & $\begin{array}{l}10.9^{* *} \\
(7.0)\end{array}$ & $\begin{array}{l}14.9^{m *} \\
(6.1)\end{array}$ \\
\hline$\%$ of County Population Urban & $\begin{array}{l}71.2 \\
(29.2)\end{array}$ & $\begin{array}{l}79.7^{* *} \\
(25.3)\end{array}$ & $\begin{array}{l}79.7^{* *} \\
(25.3)\end{array}$ & $\begin{array}{l}56.0^{\prime \prime \prime \prime} \\
(30.4)\end{array}$ \\
\hline$\%$ of County Households w/ Female Head & $\begin{array}{l}16.3^{* *} \\
(6.0)\end{array}$ & $\begin{array}{l}15.1^{*} \\
(4.4)\end{array}$ & $\begin{array}{l}11.0^{* *} \\
(4.1)\end{array}$ & $\begin{array}{l}10.0^{\prime \prime \prime} \\
(3.0)\end{array}$ \\
\hline Racial Homogeneity Index & $\begin{array}{l}.62^{* *} \\
(.18)\end{array}$ & $\begin{array}{l}.71^{*} \\
(.16)\end{array}$ & $\begin{array}{l}.86^{* *} \\
(.14)\end{array}$ & $\begin{array}{l}.93^{* \prime \prime} \\
(.07)\end{array}$ \\
\hline$\%$ of County Population African-American & $\begin{array}{l}17.1^{*} \\
(16.0)\end{array}$ & $\begin{array}{l}12.7^{*} \\
(11.4)\end{array}$ & $\begin{array}{l}4.4^{* *} \\
(8.9)\end{array}$ & $\begin{array}{l}1.8^{n *} \\
(2.5)\end{array}$ \\
\hline$\%$ of County Population Hispanic & $\begin{array}{l}10.2^{*} \\
(15.0)\end{array}$ & $\begin{array}{l}6.6^{* *} \\
(13.3)\end{array}$ & $\begin{array}{l}3.4^{*} \\
(7.8)\end{array}$ & $\begin{array}{l}1.2^{* 4} \\
(1.6)\end{array}$ \\
\hline Gini Coefficient on Household Incorne & $\begin{array}{l}.41^{* *} \\
(.02)\end{array}$ & $\begin{array}{l}.39^{* *} \\
(.02)\end{array}$ & $\begin{array}{l}.37^{* *} \\
(.02)\end{array}$ & $\begin{array}{l}.38^{\prime \prime \prime} \\
(.02)\end{array}$ \\
\hline $\begin{array}{l}\% \text { of County Households with Income Less } \\
\text { than } \$ 20,000\end{array}$ & $\begin{array}{c}63.6^{* *} \\
(9.2)\end{array}$ & $\begin{array}{l}54.8^{* *} \\
(9.8)\end{array}$ & $\begin{array}{c}56.2^{* *} \\
(9.8)\end{array}$ & $\begin{array}{c}63.4 \\
(12.5)\end{array}$ \\
\hline County Median Income & $\begin{array}{l}15321^{* *} \\
(3126)\end{array}$ & $\begin{array}{l}18375^{* *} \\
(3352)\end{array}$ & $\begin{array}{l}17980^{*} \\
(3249)\end{array}$ & $\begin{array}{l}15810^{4 *} \\
(3837)\end{array}$ \\
\hline $\begin{array}{l}\% \text { of County Households with Income Greater } \\
\text { than } \$ 40,000\end{array}$ & $\begin{array}{l}7.8^{* *} \\
(4.2)\end{array}$ & $\begin{array}{l}10.1^{*} \\
(4.5)\end{array}$ & $\begin{array}{l}8.2^{*} \\
(3.9)\end{array}$ & $\begin{array}{l}6.3^{* \prime \prime} \\
(3.4)\end{array}$ \\
\hline Religious Homogeneity Index & $\begin{array}{l}.10^{* *} \\
(.09)\end{array}$ & $\begin{array}{l}.11 \\
(.12)\end{array}$ & $\begin{array}{l}.11^{\circ *} \\
(.07)\end{array}$ & $\begin{array}{l}.15^{\prime \prime \prime} \\
(.08)\end{array}$ \\
\hline
\end{tabular}

${ }^{*}\left({ }^{* *}\right)$ indicates the mean is different from the mean in the next highest catagory at a .05 (.01) level.

\# (\#\#) indicates that the mean in the highest catagory is different from the mean in the lowest catagory at a $.05(.01)$ level.

Standard deviations in parenthesis. Cell sizes are 5927, 2780, 1184, and 698 for all variables except $\ln$ (hourly wage) and starting salary of public school teacher with a B.A., both of which have fewer observations in each cell. 
Appendix Table 2

Variable Definitions and Descriptive Statistics

Variable

Highest Grade Completed by Age 24

Ln(Hourly Wage at Age 24) $1990 \$$

High School Graduate by Age 19

Starting Salary Teacher w/ B.A. 1980\$

Per-Pupil Spending in the Public Schools

(County Average) 1980\$

$\%$ of County Secondary School

Enrollment in Catholic Schools

$\%$ of County Secondary School

Enmollment in Private Schools

$\%$ of County Elementary \& Secondary

Enrollment in Private Schools

$\%$ of County Population Catholic

$\%$ of County Population Lutheran

$\%$ of County Population Jewish

$\%$ of County Population Episcopalian

$\%$ of County Population Regularly

Attend Religious Services (Any Denom)

$\%$ of County Population Urban

$\%$ of County Households w/ Female Head

Racial Homogeneity (Herfindal) Index

$\%$ of County Population African-American

$\%$ of County Population Hispanic

Gini Coefficient for Household Income

$\%$ of County Households w/ Income $<\$ 20000$

Median Income in County $1982 \$$

$\%$ of County Households w/ Income $>\$ 40000$

$\%$ of County Population w/ Educ $>=12$ yrs

$\%$ of County Population w/ Educ $>=16$ yrs

$\%$ of County Population Male

Religious Homogeneity (Herfindal) Index

Parents' Highest Grade Completed

Lirican-American

Hispanic

Frmale

Raised in a Catholic Household

Raised in a Lutheran Household

Raised in a Methodist Household

Raised in a Baptist Housebold

Raised in an Episcopalian Household

Raised in a Jewish Household

Raised in a Presbyterian Household

Raised in a Conservative Christian Household

Raised in an Other Denomination Household

Raised in a No Religion Household

Alabama

\section{$\underline{\text { Obs }}$}

10589

7882

10589

6776

10589

10589

10589

10589

10589

10589

10589

10589

10589

10589

10589

10589

10589

10589

10589

10589

10589

10589

10589

10589

10589

10589

10589

10589

10589

10589

10589

10589

10589

10589

10589

10589

10589

10589

10589

10589

10589

\section{Mean}

1.9550

.7107

10875

2199

4.4693

7.5739

10.6284

21.2348

3.9026

.3402

1.2043

53.2280

72.0043

14.9829

.6879

13.5032

7.8923

.3966

60.4683

16452.2

8.3573

64.1040

15.0408

51.5024

.1091

11.7515

.2435

.1458

.4965

.3176

.0580

.0837

.2859

.0158

.0098

.0274

.0507

.1047

.0427

.0339
Std. Dev.

2.1848

.4843

.4534

1141

517

5.3307

5.0988

6.8211

17.0645

6.5824

.4981

1.0943

5.4877

28.2121

5.6733

.1931

14.5932

13.7019

.0243

10.5007

3541.84

4.3407

10.6767

5.7422

1.3023

.0989

3.2455

.4292

.3529

.5000

.4655

.2339

.2770

.4518

.1249

.0986

.1634

.2194

.3062

.2023

.1812
Min $\underline{\text { Max }}$

$\begin{array}{rr}0 & 20 \\ .6931 & 4.2214 \\ 0 & 1 \\ 5000 & 22534\end{array}$

500

8084

87.0748

23.5298

35.6

100

72.6402

3.7373

25.9781

$32.8161 \quad 100$

$\begin{array}{rr}0 & 100 \\ 4.2801 & 36.5443\end{array}$

.3227

84.1589

96.8569

$\begin{array}{rr}.3069 & .4780\end{array}$

$27.5665 \quad 87.1643$

$7030 \quad 30011$

31.1809

$26.6446 \quad 89.8954$

$\begin{array}{ll}1.5906 & 42.8056\end{array}$

$27.7333 \quad 55.0212$

$.0001 \quad .9156$

20 
Appendix Table 2 Continued

Variable Definitions and Descriptive Statistics

\begin{tabular}{l} 
Variable \\
\hline Alaska \\
Arizona \\
Arkansas \\
California \\
Colorado \\
Connecticut \\
Delaware \\
District of Columbia \\
Florida \\
Georgia \\
Hawaii \\
Idaho \\
Illinois \\
Indiana \\
Iowa \\
Kansas \\
Kentucky \\
Louisiana \\
Maine \\
Maryland \\
Massachusetts \\
Michigan \\
Minnesota \\
Mississippi \\
Missouri \\
Montana \\
Nebraska \\
Nevada \\
New Hampshire \\
New Jersey \\
New Mexico \\
New York \\
North Carolina \\
North Dakota \\
Ohio \\
Oklahoma \\
Oregon \\
Pennsylvania \\
Rhode Island \\
South Carolina \\
South Dakota \\
Tennessee \\
Texas \\
Utah \\
Vermont \\
Virginia \\
Washington \\
\hline
\end{tabular}

\begin{tabular}{ccr} 
Obs & Mean & Std. Dev. \\
\hline 10589 & .0015 & .0388 \\
10589 & .0114 & .1062 \\
10589 & .0122 & .1101 \\
10589 & .1016 & .3021 \\
10589 & .0189 & .1364 \\
10589 & .0208 & .1429 \\
10589 & .0010 & .0322 \\
10589 & .0085 & .0923 \\
10589 & .0420 & .2006 \\
10589 & .0274 & .1634 \\
10589 & .0011 & .0336 \\
10589 & .0010 & .0322 \\
10589 & .0347 & .1831 \\
10589 & .0194 & .1381 \\
10589 & .0111 & .1049 \\
10589 & .0063 & .0792 \\
10589 & .0039 & .0628 \\
10589 & .0082 & .0902 \\
10589 & .0006 & .0257 \\
10589 & .0113 & .1058 \\
10589 & .0204 & .1416 \\
10589 & .0509 & .2198 \\
10589 & .0201 & .1404 \\
10589 & .0079 & .0887 \\
10589 & .0249 & .1559 \\
10589 & .0076 & .0871 \\
10589 & .0045 & .0671 \\
10589 & .0017 & .0423 \\
10589 & .0016 & .0411 \\
10589 & .0366 & .1878 \\
10589 & .0107 & .1032 \\
10589 & .0695 & .2543 \\
10589 & .0396 & .1951 \\
10589 & .0013 & .0363 \\
10589 & .0638 & .2445 \\
10589 & .0175 & .1313 \\
10589 & .0051 & .0718 \\
10589 & .0432 & .2034 \\
10589 & .0002 & .0168 \\
10589 & .0263 & .1601 \\
10589 & .0033 & .0573 \\
10589 & .0158 & .1249 \\
10589 & .0723 & .2590 \\
10589 & .0017 & .0423 \\
10589 & .0039 & .0628 \\
10589 & .0091 & .0952 \\
10589 & .0134 & .1150
\end{tabular}

\begin{tabular}{cc} 
Min & Max \\
\cline { 2 - 2 } 0 & 1 \\
0 & 1 \\
0 & 1 \\
0 & 1 \\
0 & 1 \\
0 & 1 \\
0 & 1 \\
0 & 1 \\
0 & 1 \\
0 & 1 \\
0 & 1 \\
0 & 1 \\
0 & 1 \\
0 & 1 \\
0 & 1 \\
0 & 1 \\
0 & 1 \\
0 & 1 \\
0 & 1 \\
0 & 1 \\
0 & 1 \\
0 & 1 \\
0 & 1 \\
0 & 1 \\
0 & 1 \\
0 & 1 \\
0 & 1 \\
0 & 1 \\
0 & 1 \\
0 & 1 \\
0 & 1 \\
0 & 1 \\
0 & 1 \\
0 & 1 \\
0 & 1 \\
0 & 1 \\
0 & 1 \\
0 & 1 \\
0 & 1 \\
0 & 1 \\
0 & 1 \\
0 & 1 \\
0 & 1 \\
0 & 1 \\
0 & 1 \\
0 & 1 \\
0 & 1
\end{tabular}


Appendix Table 2 Continued

Variable Definitions and Descriptive Statistics

Variable

West Virginia

Wisconsin

Wyoming

\begin{tabular}{ccr} 
Obs & Mean & Std. Dev. \\
\cline { 3 - 3 } & & \\
10589 & .0153 & .1231 \\
10589 & .0323 & .1770 \\
10589 & .0000 & .0097
\end{tabular}

$\underline{\text { Min } \quad \text { Max }}$

1770

0097

$\begin{array}{ll}0 & 1 \\ 0 & 1 \\ 0 & 1\end{array}$

Data from Private Schools in America:

20050 private schools: 9985 Catholic, 1516 Lutheran, 438 Jewish, 322 Episcopal, 169 Calvinist, 14 Eastern Orthodox, 52 Friends, 65 Methodist, 60 Presbyterian, 1176 7th Day Adventist, 1532 Other Religious Denomination, 4277 Not Affiliated with a Religious Denomination; 12622 Elementary, 126 Middle School, 3348 Combined K-12, 2417 Secondary, 1148 Vocational/Technical/Special Education;

Notes:

The racial homogeneity index is a Herfindal Index (sum of the squared county population shares) of (NonHispanic) Whites, (Non-Hispanic) African-Americans, Hispanics, Asians, and Native Americans.

The religious homogeneity index is a Herfindal Index of the major U.S. denominations.

Parents' highest grade completed is the maximum of mother's highest grade completed and father's highest grade completed. If only one parent's highest grade completed is reported, it becomes parents' highest grade completed.

Denominational population shares are for 1980. Other county characteristics are for 1980 or 1982 . Catholic school characteristics are for 1979. 